\title{
Curcumin, Cardiometabolic Health and Dementia
} \\ 1 Department of Food and Nutrition/Institute of Agriculture and Life Science, Gyeongsang National University, \\ Jinju 52828, Korea \\ 2 School of Pharmacy and Medical Sciences, University of South Australia, General Post Office Box 2471, \\ Adelaide, SA 5001, Australia; peter.clifton@unisa.edu.au \\ * Correspondence: yoona.kim@gnu.ac.kr; Tel.: +82-55-772-1432
}

Received: 19 August 2018; Accepted: 20 September 2018; Published: 24 September 2018

\begin{abstract}
Current research indicates curcumin [diferuloylmethane; a polyphenolic compound isolated from the rhizomes of the dietary spice turmeric (Curcuma longa)] exerts a beneficial effect on health which may be partly attributable to its anti-oxidative and anti-inflammatory properties. The aim of this review is to examine potential mechanisms of the actions of curcumin in both animal and human studies. Curcumin modulates relevant molecular target pathways to improve glucose and lipid metabolism, suppress inflammation, stimulate antioxidant enzymes, facilitate insulin signalling and reduce gut permeability. Curcumin also inhibits $A \beta$ and tau accumulation in animal models and enhances mitochondria and synaptic function. In conclusion, in high-dose animal studies and in vitro, curcumin exerts a potential beneficial effect on cardiometabolic disease. However, human studies are relatively unconvincing. More intervention studies should be conducted with the new curcumin formulation with improved oral bioavailability.
\end{abstract}

Keywords: Curcumin; glucose; insulin resistance; inflammation; type 2 diabetes

\section{Introduction}

Type 2 diabetes Mellitus (T2DM) is associated with impaired insulin signalling, leading to hyperglycaemia and micro and macrovascular diseases [1,2]. Insulin resistance is a major contributor to the pathogenesis of T2DM with secondary pancreatic failure [2,3]. The prevalence of diabetes mellitus will increase worldwide from 451 million people aged over 18 in 2017 to 693 million people in 2045 [4]. Diabetes is an enormous social, financial and health system burden across the world [4,5]. Lifestyle modification, including a healthy diet, can lower the risk of T2DM [6]. Dietary polyphenols have been a major research focus to reduce the risk of T2DM [7-10]. This review aims to present an update on the effect of curcumin (a polyphenol) on the prevention and treatment of T2DM and cardiovascular disease (CVD) in animal studies and human studies.

\section{Curcumin}

Turmeric obtained from the dried Curcumin longa L. (ginger family) is a curry spice. This is widely consumed as a food ingredient and has long been used for medicinal purposes in China and Southeast Asia [11-13]. Turmeric is comprised of 3 curcuminoids (curcumin, demethoxycurcumin and bisdemethoxycurcumin), sugars, proteins, volatile oils (natlantone, tumerone and zingiberone) and resins [14]. Of the 3 curcuminoids, curcumin is the most active lipophilic polyphenol compound which is quite stable in the acidic $\mathrm{pH}$ of stomach $[15,16]$. Curcumin is used as a food colorant (yellow), flavouring, and additive [13]. The chemical structure of pure curcumin (diferuloylmethane) is 1,7-bis-(4-hydroxy-3-methoxyphenyl)-1, 6-heptadiene-3,5-dione and comprises two ferulic acid residues joined by a methylene bridge [17]. The structure of curcumin is shown in Figure 1. Commercially available curcumin contains $77 \%$ curcumin, 17\% demethoxycurcumin and 3\% bisdemethoxycurcumin [13]. 


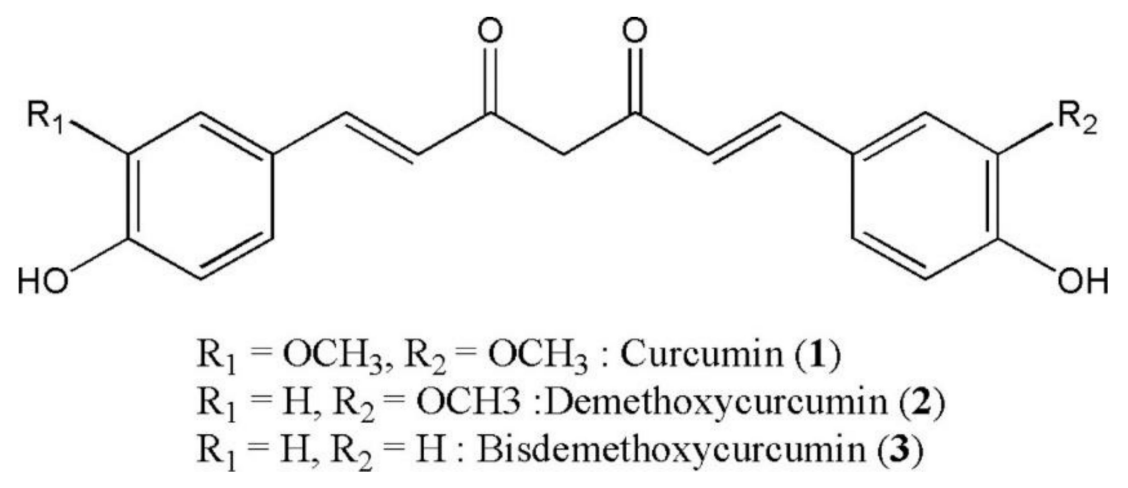

Figure 1. Chemical structure of curcuminoids.

\subsection{Curcumin Safety}

The Allowable Daily Intake (ADI) value of curcumin is $3 \mathrm{mg} / \mathrm{kg}$ body weight [18]. Healthy subjects consumed curcumins ranging from 0.5 to $12 \mathrm{~g} /$ day for $72 \mathrm{~h}$ in order to assess the safety of curcumin. Up to $12 \mathrm{~g} /$ day of curcumin consumption for $72 \mathrm{~h}$ was deemed safe. About $30 \%$ subjects showed diarrhoea and headache, which were not dose-related [19]. Subjects who consumed curcumins at a dose ranging from 0.45 to $3.6 \mathrm{~g} /$ day for $1-4$ months experienced nausea and diarrhoea. The serum concentrations of alkaline phosphatase and lactate dehydrogenase were elevated in 3-4 out of 15 patients [20].

A review article investigating the pharmacokinetic interactions of curcumin with conventional drugs (including cardiovascular drugs, antidepressants, anticoagulants, antibiotics, chemotherapeutic agents, and antihistamines) showed that curcumin can alter maximum serum concentrations (Cmax) and area under the curve (AUC) when used with those drugs. Curcumin can inhibit cytochrome P450 monooxygenases (drug-metabolising enzymes) and P-glycoprotein (an efflux pump from the ATP-binding cassette $(\mathrm{ABC})$ super family which pumps various xenobiotics (e.g., drugs) out of cells. Only one clinical trial has demonstrated a significant interaction between curcumin and drugs [21].

\subsection{Curcumin Bioavailability}

Detectable concentrations of curcumin and its metabolites in both blood and urine were observed with curcumin ingestion of $\geq 3.6 \mathrm{~g} /$ day in several studies [20,22-25]. The mean plasma concentration in patients with advanced colorectal cancer refractory to standard chemotherapies who consumed $3.6 \mathrm{~g} /$ day of curcumin for up to 4 months was $4.3 \mathrm{ng} / \mathrm{mL}$ (i.e., about $0.01 \mu \mathrm{M} / \mathrm{L}$ ). The mean plasma concentrations of curcumin glucuronide and curcumin sulphate were 5.8 and $3.3 \mathrm{ng} / \mathrm{mL}$, respectively, $1 \mathrm{~h}$ after administration [20]. The plasma concentrations (mean $\pm \mathrm{SD}$ ) of curcumin for patients with high-risk or pre-malignant lesions who took $4 \mathrm{~g}, 6 \mathrm{~g}$ and $8 \mathrm{~g}$ daily for 3 months were $0.19,0.20$, and $0.60 \mu \mathrm{g} / \mathrm{mL}$, respectively [22]. Healthy subjects $(n=6)$ ingested $10 \mathrm{~g}$ of curcumin extract after hydrolysis of conjugates. The $\mathrm{Cmax}$ (mean $\pm \mathrm{SE}$ ) of curcumin conjugates detected as glucuronide and sulphate were $3.2 \pm 0.56 \mu \mathrm{g} / \mathrm{mL}$. These values were 1000 times higher than those of other study subjects with lower doses of curcumin (mentioned above [20,22]). The time to reach maximum plasma concentrations (Tmax) was $4.33 \pm 3.2 \mathrm{~h}[25]$.

However, other studies [19,22,24-29] showed very low or even undetectable concentrations of blood curcumin after oral consumption. This may be attributable to chemical instability, low absorption, rapid metabolism, and enhanced elimination [30]. Animal studies showed that $>90 \%$ of ingested curcumin is excreted in the faeces [31]. Microbial metabolites of curcumin have been reported [32-36].

Efforts to enhance curcumin bioavailability have been made, including systemic implants, curcumin nanoparticles or curcumin with stabilised surfactants [37-42].

Different formulations are available to increase curcumin solubility, circulation, permeability, bioavailability and resistance to metabolic processes using various materials, such as adjuvants (piperine), bio-conjugates [turmeric oil, glycine, alanine and epigallocatechin-3-gallate (EGCG)], lipids (phospholipid), nanoparticles (liposome, micelles, noisome, nanogels, chitosan, gold, silver, 
cyclodextrin, dendrimer, solid lipids), protein (BSA, soy protein isolated) and others (hyaluronic acid, hydrogel, polymer, PEG-PEI emulsion, polymer encapsulated, beta-lactoglobulin) $[26,43,44]$. Adjuvant piperine (extracted from black pepper, which suppresses rapid glucuronidation of curcumin in liver and intestine and then decreases urinary excretion of curcumin), when used with curcumin, increases free curcumin in tissues leading to increased curcumin bioavailability by 2000 times [26]. Human interventions showed a favourable effect of the formulation of curcumin with piperine on anthropometric parameters and lipid profiles $[45,46]$.

Curcumin bioavailability increased 7 to 8 times when curcumin was bio-conjugated with turmeric oil (Biocurcumax ${ }^{\mathrm{TM}}$ Arjuna Natural Extracts Ltd., Kerala, India) [47]. The formulation of curcumin bio-conjugates with epigallocatechin-3-gallate (EGCG) [48] and with glycine, alanine and turmeric oil [49] enhanced curcumin uptake into cells in vitro. The phospholipid-curcumin complex enhanced bioavailability [50]. A liposome (25-205 $\mathrm{nm}$ in diameter)-curcumin complex [43] showed higher bioavailability than unformulated curcumin.

Noisomes (190-1140 nm in diameter) showed increased curcumin bioavailability [51]. A curcumin micelle (10-100 nm in diameter) with a nano-sized core and a membrane of hydrophilic polymer showed enhanced bioavailability [43,52-56]. In a human intervention, nano-micelle curcumin showed beneficial effects on glucose and lipid profiles in diabetic patients [57]. Moreover, nanogel (10-200 nm in diameter) [58], chitosan (100-250 $\mathrm{nm}$ in diameter) [59,60], gold (200-250 $\mathrm{nm}$ in diameter) [61,62], silver ( $15 \mathrm{~nm}$ in diameter) [63], cyclodextrin [64], dendrimer (15-150 $\mathrm{nm}$ in diameter) [65] and solid lipids (50-1000 $\mathrm{nm}$ in diameter) [66] showed improved solubility and bioavailability of curcumin in vitro and animal studies.

A curcumin-solid lipid nanoparticle (SLNP), called “Longvida ${ }^{\circledR}$ " (Verdure Sciences, Noblesville, IN, USA) showed improved bioavailability with a plasma concentration of 0.1-0.2 $\mu \mathrm{M}$ [67]. In a human intervention, Longvida ${ }^{\circledR}$ showed favourable effects on lipid profiles and memory and mood [68].

Modified curcumin chemical structures (analogues or derivatives of curcumin) have been developed with enhanced stability, solubility, bioavailability and biological effects. Rapid absorption ( $2 \mathrm{~h}$ and $57 \mathrm{~min}$ ) and slow elimination ( $3 \mathrm{~h}$ and $39 \mathrm{~min}$ half-life) were shown [69]. Bioavailability was $60 \%$ when $32 \mathrm{mg} / \mathrm{kg}$ of curcumin analogue (EF-24) was orally administrated to mice [69].

The first curcumin nanoparticle (Theracurmin ${ }^{\circledR}$, Theravalues Corp., Kioicho Chiyoda-ku, Tokyo, Japan) showed enhanced bioavailability in healthy subjects [70]. The t1/2 was $9.7 \pm 2.1 \mathrm{~h}$ for $150 \mathrm{mg}$ and $13.0 \pm 3.3 \mathrm{~h}$ for $210 \mathrm{mg}$ and plasma curcumin was still detectable at the 24-h time point [70]. In a human intervention, Theracurmin ${ }^{\circledR}$ with $90 \mathrm{mg}$ of curcumin twice daily showed favourable effects on memory and attention [71].

\section{Effects of Curcumin on Cardiometabolic Health}

A summary of curcumin human intervention studies is shown in Table 1.

\subsection{Anti-Oxidative Effects}

Oxidative stress is characterised by an imbalance between reactive oxygen species (ROS) generation and anti-oxidative defence [72]. Hyperglycemia promotes autooxidation of glucose, glycation of protein and enhanced polyol pathways leading to the increased ROS [73]. Continuous oxidative stress can cause chronic inflammation which may result in chronic diseases such as T2DM, CVD and Alzheimer's disease (AD) [74-77].

The anti-oxidant effect of curcumin as a free radical scavenger appear to be related to its phenolic $\mathrm{O}-\mathrm{H}$ and $\mathrm{C}-\mathrm{H}$ groups [78].

\subsubsection{Human Studies}

There are fewer than 30 human studies, and most are small and uncontrolled, so the data is relatively unconvincing. However, it is noted that volunteer characteristics and experimental designs were rarely the same in different studies. 
Thirty-eight healthy middle-aged subjects (40-60 years old) who consumed a low dose of lipidated curcumin ( $80 \mathrm{mg} /$ day) for 4 weeks showed some favourable effects on cardiometabolic health, but no comparison was made with placebo, so no firm conclusions can be drawn [79].

Yang et al. 2015 [80] conducted a small open uncontrolled study to see if curcumin intake in subjects with T2DM can lower urinary microalbuminuria excretion. Urinary microalbuminuria was significantly decreased by $70 \%(n=14 ; p<0.05)$ by $500 \mathrm{mg} /$ day of curcumin for 15 days. Moreover, decreased levels of malondialdehyde (MDA) and increased levels of nuclear factor erythroid 2-related factor 2 (Nrf2), $\mathrm{NAD}(\mathrm{P}) \mathrm{H}$ : quinone oxidoreductase (NQO1), superoxide dismutase (SOD) were observed. The levels of lipopolysaccharides (LPS) and caspase 3 decreased. The levels of I $\mathrm{K} \mathrm{B} \alpha$ and gut barrier function increased in a before and after comparison. There were no significant differences in fasting blood glucose, insulin, C-peptide, triglyceride (TG), total cholesterol (TC), HDL-C, low-density lipoprotein (LDL-C), alanine transaminase (ALT), aspartate transaminase (AST), creatinine and urea nitrogen (BUN) following 15-day curcumin ingestion compared with the baseline [80].

In a randomised, double-blind, placebo-controlled, crossover study, 62 overweight/obese women aged over 40-75 years (mean body mass index (BMI) $\geq 34.5 \pm 0.8 \mathrm{~kg} / \mathrm{m}^{2}$ ) with C-reactive protein $(C R P)=8.05 \pm 1.33 \mathrm{mg} / \mathrm{L}$ who were treated with $2.8 \mathrm{~g} /$ day of turmeric $(\sim 112 \mathrm{mg} /$ day curcumin $)$ for 4 weeks showed no changes in oxidative stress (F2-iso-prostanes, oxidised LDL-C), inflammatory markers (CRP, IL-6, IL-8, IL-10, tumour necrosis factor $\alpha$ (TNF $\alpha$ ), IFN $\gamma$, IL-1 $\beta$ and IL-12p70), serum glucose, body weight, percent body fat, systolic blood pressure, augmentation index when compared with either the placebo or the baseline [81].

\subsubsection{Several Possible Mechanisms of Curcumin Anti-Oxidant Activity Have Been Proposed [82-93]}

Severe oxidative stress can cause DNA damage and stimulate the DNA repair enzyme poly ADP-ribose polymerase-1 (PARP-1). Inhibition of PARP-1 reduces tissue injury in oxidative stress-related diseases (e.g., T2DM and CVD) [94,95]. Curcumin suppressed ROS in islets of streptozotocin-induced diabetic rats by increasing $\mathrm{Cu} / \mathrm{Zn}$ SOD and reduced PARP-1 activity, which is a secondary response to inhibition of ROS-related damage [91].

Curcumin reduced thiobarbituric acid reactive substances (TBARS), lipid peroxidation and MDA, and increased antioxidant enzyme activities such as SOD, catalase (CAT), glutathione peroxidase (GPx) and glutathione-S-transferase (GST) in erythrocytes, liver, kidney, heart, pancreas and brain of diabetic animals $[87,88,93]$ but very high doses were used (e.g., $100 \mathrm{mg} / \mathrm{kg}$ ).

Curcumin $(0-10 \mu \mathrm{m} / \mathrm{L})$ reduced haemoglobin glycosylation and lipid peroxidation in erythrocytes under oxidative stress induced by high glucose concentrations [83], and inhibited aldose reductase which in turn leads to decreased intracellular sorbitol accumulation [84]. Elevated aldose reductase activities cause increased sorbitol production from glucose, which may increase diabetes complications $[85,86]$. It is noted that recent studies indicate aldose reductase inhibitors alone appear to be not effective for prevention of diabetic complications [96,97].

In alloxan-induced diabetic rats, a glucose-lowering of curcumin $(1 \mathrm{~g} / \mathrm{kg}$ body weight or $0.08 \mathrm{~g} / \mathrm{kg}$ body weight) was noted, which led to reduced oxidative stress (decreased TBARS) through the prevention of glucose influx into the polyol pathway, as well as a decrease in sorbitol dehydrogenase (SDH—converts sorbitol to fructose) [82].

Curcumin $(20 \mu \mathrm{m} / \mathrm{L}$ or $40 \mu \mathrm{m} / \mathrm{L})$ activated the expression of antioxidant enzymes including $\gamma$-glutamyl-cysteine ligase (GCLM), NQO1 and heme oxygenase 1 (HO-1) in pancreatic $\beta$ cells and adipocytes $[89,98]$. The expression of HO-1 was induced by curcumin through the activation of Nrf2/antioxidant-responsive element (ARE) pathway in renal epithelial cells [90]. It is noted that Nrf2 is closely associated with oxidative stress-induced inflammation [99].

\subsection{Anti-Inflammatory Effects}

A meta-analysis of 8 randomised controlled trials (RCTs) [79,100-106] in subjects with a variety of diseases showed that curcuminoids significantly lowered CRP levels (by a mean $2.2 \mathrm{mg} / \mathrm{L}$ ) compared 
with a placebo [107]. In a meta-analysis of RCTs [108-113], curcumin significantly reduced TNF- $\alpha$ (weight mean difference $-4.69 \mathrm{pg} / \mathrm{mL} ; 95 \% \mathrm{CI}:-7.10,-2.28 ; p<0.001$ ) [114]. In a meta-analysis of 9 RCTs $[102,103,106,108,109,111,112,115,116]$ in subjects with different diseases, curcumin significantly lowered IL-6 by $0.6 \mathrm{pg} / \mathrm{mL}(P=0.01)$ compared with control [117]. Curcumin supplement $(1 \mathrm{~g} /$ day, $n=59$ ) for 8 weeks significantly decreased TNF- $\alpha$, IL- 6 , transforming growth factor beta (TGF- $\beta$ ) and monocyte chemoattractant protein 1 (MCP-1) compared with placebo [112]. In a randomised, double-blind, crossover trial of 30 obese subjects with BMI $\geq 30$, curcumin treatment $(1 \mathrm{~g} /$ day) for 4 weeks significantly decreased IL-4, IL-1 $\beta$ and vascular endothelial growth factor (VEGF) without differences in IL-2, IL-6, IL-8, IL-10, IFN $\gamma$, epidermal growth factor (EGF), and MCP-1, compared with a placebo [111].

Curcumin and Inflammatory Pathways

A mitogen-activated protein kinase (MAPK) regulates embryogenesis, cell differentiation, proliferation, survival and death [118,119]. The MAPK pathway is comprised of a series of protein kinases [118-120]. The p38 MAPK pathway is associated with inflammatory responses [121,122].

TNF- $\alpha$ and LPS activate PI 3-kinase in human intestinal microvascular endothelial cells (HIMEC), and subsequently increase serine/threonine kinase (Akt) phosphorylation for Akt activation. Activated Akt stimulates MAPK and nuclear factor kappa B (NF-kB) signalling pathways resulting in vascular cell adhesion molecule (VCAM-1) and MAdCAM-1 expression in the intestine $[123,124]$.

Curcumin suppressed nitric oxide, MCP-1, IL-1 $\beta$, IL-6, TNF- $\alpha$, cyclooxygenase-2 (COX-2) and prostaglandin E2 (PGE2) by suppressing Jun NH2-terminal kinase (JNK), extracellular signal-regulated kinase1/2 (ERK1/2) and p38MAPK in adipocytes in vitro [125-127] and in other organs [128-131].

Curcumin may reduce diabetes complications related to vascular inflammation. Hyperglycaemic conditions induce the secretion of proinflammatory cytokines via epigenetic changes, which are mediated by the opposing actions of histone deacetylases (HDACs) and histone acetylases (HATs) [132,133]. Curcumin treatment of human monocytic (THP-1) cells under high-glucose conditions increased HDAC2, decreased HATs activity and expressions of p300 and acetylated CBP/p300 gene expression, consequently leading to decreased NF- $\mathrm{KB}$ transcription activity and proinflammatory cytokine secretion (IL-6, TNF- $\alpha$ ) [132].

Oxidative stress and inflammation are contributors to cardiometabolic disease including insulin resistance, T2DM, CVD and AD. The potent anti-oxidative and anti-inflammatory effects of curcumin could beneficially influence glucose and lipid homeostasis and endothelial function.

\subsection{Glucose Homeostasis}

In a randomised double-blind, placebo-controlled study, subjects with non-alcoholic fatty liver disease (NAFLD) (mean age $46.37 \pm 11.57$ years; mean BMI $31.35 \pm 5.67 \mathrm{~kg} / \mathrm{m}^{2} ; n=77$ ) consumed $500 \mathrm{mg} /$ day of an amorphous dispersion curcumin formulation (equivalent to $70 \mathrm{mg}$ curcumin) for 8 weeks. Curcumin consumption significantly reduced glucose, glycated haemoglobin ( $\mathrm{HbA1c}$ ), TC, LDL, TG, liver fat content, BMI, aspartate aminotransferase (AST), alanine aminotransferase (ALT) compared with the placebo [134]. All the changes seen may be due to the loss of weight seen in the curcumin group (over $2 \mathrm{~kg}$ difference over 8 weeks), which may be caused by nausea and anorexia, which caused 3 dropouts as well. Ultrasound is not a reliable method amount of liver fat. Large changes in $\mathrm{HbA} 1 \mathrm{c}$ were seen in both groups. In a randomised double-blind, placebo-controlled trial of 100 overweight/obese subjects with T2DM (average age: $54.72 \pm 8.34$ years; BMI $\geq 24.0$; curcuminoids ( $300 \mathrm{mg} /$ day; $n=50$ ) supplementation for 12 weeks significantly reduced fasting glucose, $\mathrm{HbA1c}$ and homeostasis model assessment insulin resistance (HOMA-IR) with decreased levels of serum free fatty acids (FFAs) and TG, and increased lipoprotein lipase (LPL) activity compared with a placebo. However, levels of TC, LDL- C, HDL- C, Apo A-I or Apo B did not differ. Anthropometric variables such as body weight and waist and hip circumferences were also not altered on curcuminoids supplementation compared with a placebo [135]. 
In a randomised, double-blind, placebo-controlled trial of prediabetic subjects $(n=237)$, curcumin treatment (a total of 6 capsules/day-250 mg curcuminoid/capsule) significantly decreased $\mathrm{HbA1c}$, fasting glucose and OGTT at 3,6, and 9 months compared with a placebo $(p<0.01)$ and reduced the diagnosis of $\mathrm{T} 2 \mathrm{DM}$ from $16.9 \%$ to $0 \%$. At 3 months, curcumin treatment significantly increased HOMA- $\beta(p<0.01)$ compared with a placebo. At 9 months, C-peptide and insulin were significantly attenuated with curcumin treatment compared with a placebo $(p<0.05)$. Moreover, curcumin treatment significantly reduced HOMA-IR at 6 and 9 months and elevated adiponectin at 9 months compared with a placebo [136]. Curcumin treatment significantly decreased body weight by $6.2 \mathrm{~kg}$ at 9 months compared with a placebo which could account for all of the observations on glucose and $\mathrm{HbA} 1 \mathrm{c}$. AST, ALT, creatinine, bone mineral density and waist circumference were not altered with curcumin treatment compared with a placebo. This clinical study supports the preventive effect of curcumin on the development of T2DM in individuals with prediabetes [136].

Adiponectin acts as an insulin sensitiser to suppress hepatic gluconeogenesis via AMP-activated protein kinase (AMPK)-dependent and -independent pathways. It stimulates fatty acid oxidation predominantly in skeletal muscle to activate glucose uptake [137]. Increased adiponectin levels were observed with curcumin supplementation ( $1 \mathrm{~g} /$ day) for 6 weeks in subjects with metabolic syndrome compared with a curcumin-phospholipid complex group or a placebo group, whereas no differences in BMI, body weight, waist circumference, fasting blood glucose, fat (\%) were observed compared with a curcumin-phospholipid complex group or a placebo group [138].

In a randomised double-blind, placebo-controlled design, subjects with T2DM (mean age $59 \pm 10.6$ years; $n=107$ ) were treated with $250 \mathrm{mg}$ of curcumin (3 times/day) for 6 months. Curcumin treatment increased adiponectin and decreased leptin levels compared with the placebo. Pulse wave velocity (PWV), HOMA-IR, $\mathrm{TG}$, uric acid, abdominal obesity (visceral fat and total body fat) were significantly reduced with curcumin treatment compare with the placebo [139].

In a randomised crossover study, 11 healthy subjects supplemented with turmeric ( $2.8 \mathrm{~g} /$ day) for 4 weeks showed no changes in fasting plasma glucose, TC and TG compared with the control (water only) [140]. In a crossover design, 14 healthy subjects who consumed $6 \mathrm{~g}$ of encapsulated turmeric with a standard $75 \mathrm{~g}$ oral glucose tolerance test (OGTT) showed increased insulin responses with no difference in postprandial glucose responses compared with the reference OGTT with placebo capsules [141].

The effect of curcumin on glucose control is inconclusive, as five RCTs [57,134-136,139] showed positive effects and ten RCTs [80,81,108,138,140,142-146] showed no effect.

\section{Potential Mechanisms of Curcumin}

On the other hand, in vitro and high-dose animal studies supports the glucose lowering effects of curcumin. A high-fat diet (HFD) was given to male Wistar rats (7 weeks of age) for 6 weeks, and then diabetes was induced by streptozotocin injection $(30 \mathrm{mg} / \mathrm{kg}$ body weight). Three different concentrations of curcumin (50,150, or $250 \mathrm{mg} / \mathrm{kg}$ body weight) were used for 7 weeks. Curcumin (especially, $150 \mathrm{mg} / \mathrm{kg}$ body weight) significantly improved glucose and insulin tolerance compared with normal control rats [147]. In addition, in the in vitro study, L6 myotube cells were treated with different concentrations of curcumin $(5,10,20$, or $40 \mu \mathrm{m} / \mathrm{L})$ in the presence of palmitate $(0.25 \mathrm{mM} / \mathrm{L})$. The 2-deoxy-[3H] D-glucose uptake was enhanced by curcumin in a dose dependent manner and glucose transporter 4 (GLUT4) protein expression increased on the cell membrane of L6 myotubes [147].

$\mathrm{C} 57 \mathrm{BL} / \mathrm{KsJ}-\mathrm{db} / \mathrm{db}$ mice and their age-matched lean non-diabetic $\mathrm{db} /+$ mice were fed a diet with curcumin or without curcumin $(0.02 \%, \mathrm{wt} / \mathrm{wt})$ for 6 weeks. In $\mathrm{db} / \mathrm{db}$ mice, curcumin decreased glucose and $\mathrm{HbA1c}$, improved HOMA-IR and glucose tolerance as assessed by intraperitoneal glucose tolerance test (IPGTT) and increased insulin levels. Curcumin did not alter glucose tolerance and insulin levels in $\mathrm{db} /+$ mice. Curcumin increased hepatic glucokinase (GK) activity and suppressed the elevation of hepatic gluconeogenic enzyme activities, glucose-6-phosphatase (G6Pase) and phosphoenolpyruvate carboxykinase (PEPCK) in $\mathrm{db} / \mathrm{db}$ mice. Curcumin increased glycogen storage in the liver in the $\mathrm{db} / \mathrm{db}$ 
mice, while curcumin did not alter hepatic GK, P6Pase, PEPCK and glycogen content in non-diabetic $\mathrm{db} /+$ mice. These findings indicate that curcumin can lower glucose levels in $\mathrm{db} / \mathrm{db}$ mice [93].

AMPK plays a key role in glucose and fatty acid metabolism [148]. Its roles in activation of catabolic processes aimed at ATP production (e.g., glucose uptake, glycolysis, fatty acid uptake, and $\beta$-oxidation) and inhibition of anabolic pathways (e.g., synthesis of glycogen, proteins, fatty acids, and cholesterol) have been well documented [149].

Curcumin treatment $(10-20 \mu \mathrm{m} / \mathrm{L}, 10 \mu \mathrm{m} / \mathrm{L}$, or 15,30 and $60 \mathrm{mg} / \mathrm{kg}$ body weight $)$ elevated insulin sensitivity by increasing insulin receptor substrate-1 (IRS1) protein, Akt, extracellular signal-regulated protein kinases 1 and 2 (ERK1/2), p38 MAPK, and AMPK in C2C12 skeletal muscle cells [150], L6 myotube cells [151] and in the liver of fructose-fed rats [152]. Curcumin $(10 \mu \mathrm{m} / \mathrm{L})$ also increased insulin sensitivity in skeletal muscle by promoting oxidation of glucose and fatty acid mediated in part through serine-threonine liver kinase B1 (LKB1)-AMPK pathway [147].

Curcumin $(10 \mu \mathrm{m} / \mathrm{L})$ improved insulin secretion by activating phosphoinositide 3-kinase (PI3K) or Akt, inhibiting forkhead box protein O1 (FoxO1), alleviating endoplasmic reticulum (ER) stress and enhancing mitochondrial survival from lipotoxicity in palmitate-treated MIN 6 pancreatic $\beta$ cells [153].

Curcumin $(2-10 \mu \mathrm{m} / \mathrm{L})$ lowered glucose by stimulating $\beta$-cell function by activating the volumeregulated anion channel enhancing insulin secretion in rat pancreatic $\beta$-cells [154]. Curcumin $(1-100 \mathrm{pmol} / \mathrm{L})$ also enhanced pancreatic $\beta$-cell function acting as a cyclic nucleotide phosphodiesterase (PDE) inhibitor. Curcumin treatment downregulated expression of PDEs (enzymes which convert cyclic AMP and cyclic GMP into $5^{\prime} \mathrm{AMP}$ and $5^{\prime}$-GMP), leading to elevated intracellular cAMP levels with improved insulin release from pancreatic $\beta$-cells [155].

In high-fat diet-induced obese and leptin-deficient ob/ob male C57BL/6J mice, the improved glucose control following curcumin treatment ( $3 \%$ dietary curcumin) was associated with anti- inflammatory effects of curcumin by decreasing macrophage infiltration into adipocytes, and by increasing adiponectin production in white adipocytes, by decreasing ER stress (elevated ER stress in adipocytes and hepatocytes is related to obesity) and perigonadal fat expression of Sirtuin 1 (SIRT1), heat shock proteins (HSP70), HSP90 and Foxo1 and decreasing NF-kB activity in liver [156]. SIRT1 is a regulator of adiponectin transcription through the activation of Foxo1 and Foxo1 and C/EBPalpha interaction in adipose tissue [157]. SIRT1 plays a role in glucose homeostasis, inducing hepatic glucose production through the deacetylation of PGC-1 $\alpha$ and by repressing peroxisome proliferator-activated receptor gamma (PPAR $\gamma)[158,159]$.

Curcumin supplementation $(15,30$ and $60 \mathrm{mg} / \mathrm{kg})$ increased IRS1 resulting in improved insulin sensitivity via increased expression of PPAR $\gamma$ and Akt and ERK1/2 in liver of fructose-fed rats [152].

\subsection{Lipid Homeostasis}

Seven RCTs $[45,68,100,134,135,139,143]$ showed positive lipid profile changes, while ten RCTs $[57,79-81,108,140,142,145,160,161]$ showed no effect. Therefore, evidence that curcumin is beneficial is still lacking.

A further meta-analysis of RCTs also showed no effect of curcumin on lipid profiles [162]. According to a 2017 position paper from an International Lipid Expert Panel, the lipid lowering effect of curcumin in human intervention studies is inconsistent, but several recent interventions report favourable effects on lipid profiles [134,143,146,163,164].

In a randomised double-blind, placebo-controlled parallel study of 117 subjects with metabolic syndrome (aged 25-75 years), supplementation of $1000 \mathrm{mg}$ /day of curcuminoids and piperine (bioperine ${ }^{\circledR}$ Sami Labs LTD, Bangalore, Karnataka, India) (100:1 ratio combination) for 8 weeks significantly lowered LDL-C, non-HDL-C, TC, TG and lipoprotein(a) [Lp(a)] and increased HDL-C, compared with the placebo. The lipid changes were significant after adjustment for baseline of BMI and lipids. No change in small dense LDL (sdLDL) was observed [163].

In a randomised placebo-controlled study of 87 subjects with non-alcoholic fatty liver disease, $1000 \mathrm{mg}$ /day of curcumin plus dietary and lifestyle intervention for 8 weeks significantly decreased TC, non-HDL-C, LDL-C, TG and uric acid compared with placebo. No differences in HbA1c, fasting 
glucose, insulin, HOMA-IR, HOMA- $\beta$, quantitative insulin sensitivity check index (QUICKI) were seen compared with placebo [146].

In a randomised, double-blind, placebo-controlled trial in 70 subjects with $\mathrm{T} 2 \mathrm{DM}$, nano-curcumin ( $80 \mathrm{mg}$ /day) for 3 months significantly reduced $\mathrm{HbA1C}$, fasting blood glucose, TG, and BMI before and after the treatment [57].

In a randomised, double-blind, placebo-controlled trial, 33 subjects aged 40-60 years with metabolic syndrome (mean BMI: $30.06 \pm 4.12 \mathrm{~kg} / \mathrm{m}^{2}$ ) were supplemented with $630 \mathrm{mg}$ of curcumin extract ( $95 \%$ curcuminoids, including curcumin, demethoxycurcumin, and bisdemethoxycurcumin) three times per day for 12 weeks. In comparison with the placebo, LDL-C significantly decreased with curcumin supplementation with no changes in weight, BMI, fasting glucose, HbA1C, TG, TC, very low-density lipoprotein (VLDL), HDL-C, Non-HDL-C and T-Chol/HDL-C ratio [143].

In a randomised, double-blind, placebo-controlled, parallel study investigating the effect of curcumin $\left(400 \mathrm{mg} /\right.$ day as Longvida $\left.{ }^{\circledR}\right)$ on cognition, mood and biomarkers in 60 elderly subjects (mean age: 68.5 years) for 4 weeks significantly lowered TC and LDL-C with the significant improvement memory and mood compared with the placebo [68].

In a randomised double-blind, placebo-controlled crossover trial, 30 subjects aged 18-65 years who were not taking lipid-lowering agent, as well as who had any conditions including BMI $\geq 30 \mathrm{~kg} / \mathrm{m}^{2}$ or 2 risk factors (except for T2DM) for coronary heart disease (CHD) or $\geq 2$ risk factors (except for T2DM) for CHD and $130 \mathrm{mg} / \mathrm{dL}<\mathrm{LDL}-\mathrm{C}<160 \mathrm{mg} / \mathrm{dL}$, were supplemented with curcuminoids ( $1 \mathrm{~g} /$ day) for 30 days. Curcuminoids supplementation decreased TG levels with no differences, LDL-C, HDL-C and CRP. Anthropometric variables such as body weight, BMI, waist circumference, arm circumference, and fat percentage also were not altered with curcuminoids supplementation compared with the placebo [100].

In a randomised double-blind, controlled trial, subjects with acute coronary syndrome, curcumin ingestion (45-180 mg/day) for 1 year showed no changes in lipids [145]. In a randomised, double-blind study of 36 elderly subjects (mean age: $73.4 \pm 8.8$ years), either $4 \mathrm{~g}$ /day or $1 \mathrm{~g} /$ day of curcumin supplementation did not significantly alter TG, LDL-C and HDL-C over 1 month or 6 months compared with a control [160]. In a double-blind, randomised, placebo-controlled, $2 \times 2$ factorial trial, 70 hypercholesterolemia subjects (mean fasting TC: $6.57 \pm 0.13 \mathrm{mM} / \mathrm{L}$ ) were randomised to either curcumin $\left(200 \mathrm{mg}\right.$ /day: Meriva ${ }^{\circledR}$ Indena) plus phytosterols $(2 \mathrm{~g} /$ day; $n=17)$ or curcumin $(200 \mathrm{mg} /$ day; $n=18)$ or phytosterols $(2 \mathrm{~g} /$ day; $n=17)$ or placebo $(n=18)$ for 4 weeks. Phytosterol group and curcumin plus phytosterol group showed significant reductions in TC, LDL-C and TC: HDL-C compared with the baseline, whereas the curcumin group did not significantly alter TC and LDL-C. HDL-C and TG were not altered in any group [161].

Potential Mechanisms of Actions of Curcumin on Lipids

In vitro [165,166] and animal studies [93,152,167-174] showed improved lipid profiles following curcumin treatment.

In the human hepatoma cell line (HepG2), a potential hypocholesterolemic effect of curcumin $(0.02 \% \mathrm{wt} / \mathrm{wt})$ was observed with elevated gene expressions of the LDL-receptor. Curcumin $(80 \mathrm{mg} / \mathrm{kg})$ has been shown to downregulate fatty acid synthase (FAS-related to increased plasma lipid levels) and increase skeletal muscle LPL [93,167].

Statins are lipid-lowering medications known as HMG-CoA reductase inhibitors. Curcumin $(0.02 \% \mathrm{wt} / \mathrm{wt})$ has been shown to decrease HMG-CoA reductase activity leading to reduced plasma and hepatic cholesterol levels $[93,175]$.

In animals fed a high-fat diet, curcumin treatment $(0.05 \mathrm{~g} / 100 \mathrm{~g}$ diet $)$ has been shown to decrease hepatic acyl-CoA: cholesterol acyltransferase (ACAT) which may decrease intestinal cholesterol uptake and transport in the intestine $[93,172]$.

Curcumin treatment $(0.5 \%$ dietary curcumin or $0.1 \% \mathrm{wt} / \mathrm{wt})$ also has been shown to increase hepatic cholesterol $7 \alpha$-hydroxylase (CYP7A) which is a rate-limiting enzyme responsible for the biosynthesis of bile acid from cholesterol [171,176,177]. 
Activated AMPK suppresses fatty acid synthesis in the liver by suppressing liver $\mathrm{X}$ receptor $\alpha$ (LXR $\alpha$ ) -dependent sterol regulatory element-binding protein [(SREBP)-1c-a major gene transcription factor for hepatic lipogenesis] [178,179]. Elevated hepatic lipogenesis is associated with insulin resistance [178,179]. In the liver, curcumin ( $4 \mathrm{~g} / \mathrm{kg}$ diet or $0.02 \% \mathrm{wt} / \mathrm{wt}$ ) suppressed SREBP1c, and the carbohydrate response element-binding protein (ChREBP) [98] and upregulated LXR $\alpha$ to decrease TG levels [175].

A cholesterol transporter, ATP-binding cassette A1 (ABCA1) transporter acts as cholesterol efflux regulatory protein. Curcumin $(5,10$ and $20 \mu \mathrm{g} / \mathrm{mL})$ has been shown to promote cholesterol efflux from adipocytes via PPAR $\gamma$-LXR $\alpha$-ABCA1 pathway (activation of PPAR $\gamma, \mathrm{LXR} \alpha$ and ABCA1) [180].

Ezetimibe, known as a Niemann-Pick C1 Like 1 (NPC1L1) inhibitor, is a cholesterol-lowering medication which reduces cholesterol absorption in the small intestine. Curcumin treatment $(50 \mu \mathrm{m} / \mathrm{L}$ or 25-100 $\mu \mathrm{m} / \mathrm{L}$ ) in Caco-2 cells inhibited NPC1L1 through the inhibition of SREBP-2 [181,182].

Curcumin treatment (100 or $400 \mathrm{mg} / \mathrm{kg}$ body weight) has been shown to decrease serum TG and fetuin-A ( $\alpha 2$-Heremans-Schmid glycoprotein) levels in liver of rats fed a high-fat diet [174]. Fetuin-A produced in the liver is associated with insulin resistance and fatty liver [183,184].

\subsection{Weight Control}

In a systematic review [185] of 8 RCTs [46,81,100,134,135,139,143,186], 3 studies [46,134,139] showed a favourable effect on weight control while 5 studies $[81,100,135,143,186]$ showed no effects [185]. Moreover, RCTs $[136,138,142]$ included in this review showed no effect, and RCTs $[45,57]$ showed a positive effect on weight control. Given the findings from limited numbers of RCTs [45,46,57,81,100,134-136,138,139,142,143,186], curcumin at usual doses is unlikely to contribute to weight control.

In a randomised double-blind, placebo-controlled trial of subjects with T2DM, curcuminoids (1000 mg/day combined with piperine $10 \mathrm{mg}$ /day) for 12 weeks significantly decreased body weight, BMI, TC and Lp(a) and increased HDL-C compared with a placebo. However, curcumin did not alter TG and LDL-C compared with the placebo [45].

In a randomised parallel trial, overweight subjects with metabolic syndrome (mean BMI 25-29.9 kg/m2; mean age $39.1 \pm 16.8$ years; $n=44$ ) who adhered to a diet plus lifestyle intervention for 30 days (adherence rate $>80 \%$ and a weight loss $<2 \%$ ) underwent either curcumin treatment (800 mg twice per day; $n=22)$ plus lifestyle intervention or phosphatidylserine plus lifestyle intervention for 4 weeks. Significant reductions in body weight, body fat, waistline and BMI were observed with curcumin treatment compared with the phosphatidylserine group [46].

On the other hand, in a randomised, double-blind, placebo-controlled, crossover study, obese subjects (mean BMI: $33.95 \pm 3.81$ ) who were treated with curcuminoids ( $1 \mathrm{~g} /$ day) for 30 days showed no differences in BMI and weight compared with the placebo [186].

\section{Potential Mechanisms}

Curcumin $(80 \mathrm{mg} / \mathrm{kg}$ diet or $500 \mathrm{mg} / \mathrm{kg}$ diet or $1.5 \mathrm{~g} / \mathrm{kg}$ diet or $4 \mathrm{~g} / \mathrm{kg}$ diet or HFD containing $0.15 \%$ curcumin) led to reduced body weight and/or body fat in HFD-fed mice [98,156,167-169]. Curcumin $(5,10,20 \mu \mathrm{m} / \mathrm{L})$ has been documented to decrease palmitate-induced insulin resistance in 3T3-L1 adipocytes [126]. Curcumin $(0-100 \mu \mathrm{m} / \mathrm{L})$ has also been shown to inhibit glucose transport in 3T3-L1 adipocytes [187-189]. Curcumin $(10,25,50$, and $75 \mu \mathrm{m} / \mathrm{L})$ induced insulin resistance by suppressing insulin-stimulated protein kinase B (Akt)/GLUT4 signalling with activation of autophagy in 3T3-L1 adipocytes [189].

Stearoyl-coenzyme A desaturase 1 (SCD-1) is a rate enzyme in the synthesis of unsaturated fatty acids [190]. Upregulation of SCD-1 may be associated with obesity, insulin resistance and atherosclerosis [191]. Curcumin $(80 \mathrm{mg} / \mathrm{kg})$ treatment for 12 weeks in HFD-induced obese mice has been shown to downregulate the expression of SCD-1 in brown adipose tissue and white adipose tissue [167].

The browning effect of white fat by curcumin has been reported in several studies [192-194]. Brown adipose tissues generate heat from fat through uncoupling proteins (UCP1) present in the mitochondrial inner membrane. Brown adipose tissues are known to play a critical role in non-shivering thermogenesis 
against cold [195]. Brown adipose tissues can be derived from white adipose tissues with stimuli including cold, and adrenergic compounds [196-201]. Thermogenic gene expression (e.g., UCP1, PGC1 $\alpha$, Prdm16, Dio2, PPAR $\gamma$, Cidea, Elovl3, Nrf1, mtTfa, and ATPsyn) and mitochondrial biogenesis are increased with the browning of white adipose tissue. Curcumin $(80 \mathrm{mg} / \mathrm{kg})$ treatment for 12 weeks in HFD-induced obese mice has been shown to upregulate mRNA expressions of UCP1 in brown adipose tissue and white adipose tissue [167].

Norepinephrine binding to beta 3 adrenoreceptors ( $\beta 3 \mathrm{AR}$ ) present in white adipose tissues are known to exert a key role in the browning of white adipose tissues [202]. Curcumin treatment (50 or $100 \mathrm{mg} / \mathrm{kg}$ ) in C57BL/6J mice elevated plasma norepinephrine levels and upregulated $\beta 3 \mathrm{AR}$ gene expression in inguinal white adipose tissues and induced browning with the decreased body weight and fat accumulation compared with control mice [192].

Curcumin $(1-20 \mu \mathrm{m} / \mathrm{L})$ induced fat browning through AMPK-mediated pathway in 3T3-L1 and primary white adipocytes [193]. Curcumin (40 and $80 \mathrm{mg} / \mathrm{kg}$ ) decreased white and brown adipocyte diameters and insulin resistance caused by a high fat diet via inhibition of SREBPs [167].

Curcumin $(25 \mu \mathrm{m} / \mathrm{L})$ also exerts an anti-adipogenic effect via stimulating the Wnt/ $\beta$-catenin signalling pathway with stimulation of downstream targets such as c-Myc and cyclin D1, and by inhibiting glycogen synthase kinase-3 beta (GSK-3 $\beta$ ) and Axin, consequently resulting in downregulation of JNK phosphorylation. Curcumin treatment in 3T3-L1 cells suppressed adipocyte differentiation by suppressing adipogenic transcription factors $(\mathrm{C} / \mathrm{EBP} \alpha, \mathrm{PPAR} \gamma$ and $\mathrm{C} / \mathrm{EBP} \alpha)$ and their downstream factors (SREBP-1 and FASN) [203].

\subsection{Gut Microbiome Changes}

Lifestyle including dietary pattern, exercise, sleep and environmental factors can affect the gut microbiota [204-207]. Gut microbial dysbiosis is associated with obesity, metabolic syndrome, diabetes, CVD and neurodegenerative diseases [208-212].

Very limited studies showed that curcumin favourably modified the gut microbiota composition [213-217]. HFD-fed rats administrated with curcumin showed enhanced diversity of bacterial strains. A HFD increased metabolic endotoxemia and gut inflammation, which decreased with curcumin administration (200 $\mathrm{mg} / \mathrm{kg})$ [217].

Gut microbial dysbiosis appears to increase gut permeability, leading to an increased inflammatory response [218]. A positive association between a high-fructose diet and/or a high-fat diet and increased gut permeability has been reported [217-220].

In vitro, LPS increases IL-1 $\beta$ which can activate p38 MAP kinases and subsequently myosin light chain kinases (MLCK). The phosphorylation of myosin light chains can increase gut permeability. Curcumin treatment decreased LPS-induced release of IL-1 $\beta$ from intestinal epithelial cells and intestinal macrophages. Curcumin $(5 \mu \mathrm{m} / \mathrm{L})$ also suppressed p38 MAPK activation by IL-1 $\beta$ and myosin light chain kinase in intestinal epithelial cells [221].

Animal studies [222-225] also showed improvement of gut permeability with the curcumin treatment. A mouse model fed a Western diet for 16 weeks exhibited elevated intestinal permeability [224]. Curcumin $(5 \mu \mathrm{m} / \mathrm{L})$ decreased plasma LPS levels and increased intestinal alkaline phosphatase activity and tight junction protein expressions (ZO-1 and claudin-1) [224].

Mitogen-activated protein kinase phosphatase 1 (MKP-1) exerts an essential role in dephosphorylating MAPK and inactivating ERK, JNK and p38 in response to stress [226,227]. Curcumin (100 mg/kg) decreased the impairment of intestinal mucosa barrier by methotrexate in rats through the activation of MKP- 1 and suppression of $\mathrm{p} 38$ and NF-kB [222]. Therefore, curcumin appears to reduce gut permeability induced by external dietary factors (e.g., a western diet) or exogenous injury by altering signal pathways, consequently leading to the prevention of a chronic inflammatory state [228]. 


\subsection{Endothelial Function}

Curcumin has a protective effect on endothelial dysfunction [108,229-234]. The improved endothelial function on curcumin treatment is attributable to several mechanisms including hypoglycaemic [229] and hypolipidemic effects [229], and anti-inflammatory [235,236], anti-oxidant activities [229,230,232,233].

In a randomised, controlled, double-blind parallel study of 59 healthy subjects, curcumin supplementation ( $200 \mathrm{mg} /$ day) for 8 weeks improved endothelial function as assessed by flow-mediated dilation (FMD) compared with placebo [237]. Sixty-seven subjects with T2DM who ingested NCB-02 (300 mg/day of curcumin) for 8 weeks showed significantly enhanced endothelial function (measured using digital plethysmography) with lower levels of MDA, ET-1, IL- 6 and TNF- $\alpha$ compared with the baseline, but statistical comparison was not made with placebo. These beneficial effects of curcumin (NCB-02) on endothelial function through anti-inflammatory and antioxidant actions are comparable to those of atorvastatin $(10 \mathrm{mg} /$ day). However, in comparison with the baseline, NCB-02 did not significantly alter fasting glucose, $\mathrm{HbA1c}$, TC, LDL-C HDL-C and TG, while atorvastatin significantly lowered TC, LDL-C and TG [108].

In a double-blind, parallel, randomised study of healthy middle-aged and older adults (45-74 years) curcumin supplementation ( $2000 \mathrm{mg} /$ day Longvida ${ }^{\circledR}$ ) for 12 weeks improved resistance artery endothelial function with enhanced forearm blood flow to brachial artery infusion of acetylcholine (FBFACh) when infused with vitamin $C$ following curcumin compared with baseline (but not placebo in any variable). Curcumin also increased brachial artery FMD. Curcumin reversed the decrease in FBFACh from the nitric oxide synthase inhibitor, NG monomethyl-L-arginine. Curcumin did not alter the levels of adiponectin, leptin, insulin, HOMA-IR, oxidised LDL-C, total antioxidant status, GPx, IL-6, TNF- $\alpha$, cortisol, epinephrine, norepinephrine and endothelin-1 (ET-1) compared with baseline or placebo [144].

Curcumin treatment $(30$ and $300 \mathrm{mg} / \mathrm{kg}$ ) in streptozotocin-induced diabetic rats reduced vascular superoxide anion (O2--) production and inhibited vascular protein kinase C (PKC-bII) resulting in improved endothelial function [232]. Vascular endothelial cell damage resulting from oxidative stress can be protected by curcumin treatment via autophagy activation. In human umbilical vein endothelial cells (HUVECs) under the condition of oxidative stress induced by hydrogen peroxide $\mathrm{H}_{2} \mathrm{O}_{2}$, curcumin treatment $(1,5$ and $10 \mu \mathrm{m} / \mathrm{L}$ ) increased microtubule-associated protein 1 light chain 3-II (LC3-II-an autophagosomal marker) in a dose-dependent manner.

Curcumin $(1,5$ and $10 \mu \mathrm{m} / \mathrm{L})$ protects vascular endothelial cells through autophagic process by inhibiting the PtdIns3K-AKT-mTOR signalling pathway and FOXO1 (a mediator of autophagy) nuclear localisation and FOXO1-related proteins [230].

Curcumin $(0.25-2.5 \mu \mathrm{m} / \mathrm{L})$ also protects vascular endothelial cells by trapping methylglyoxal (MGOa major reactive dicarbonyl compound) and reducing $\mathrm{N} \varepsilon$-(carboxymethyl) lysine (CML) formation in HUVECs. This protective effect is responsible for directly trapping MGO by curcumin [231].

Curcumin treatment $(2.5,5,10$ and $20 \mu \mathrm{m} / \mathrm{L}$ ) of HUVECs and lymphocytes (Jurkat cells) exposed to either high glucose or advanced glycation end products (AGEs) restored transmembrane potential. Curcumin treatment decreased membrane fluidity in AGE-exposed Jurkat cells or glucose-exposed Jurkat cells. In addition, curcumin treatment inhibited MCP-1 release from Jurkat cells and HUVECs exposed to AGEs or glucose showing an anti-inflammatory action [238].

Lectin-like oxidised LDL receptor-1 (LOX-1), a receptor expressed in vascular cells for oxidised LDL, contributes to the pathogenesis of diabetic atherosclerosis [239]. As the glucose concentrations (5.6 to $30 \mathrm{mM} / \mathrm{L}$ ) increased, expressions of LOX-1 gene and protein increase in human monocyte-derived macrophage (MDMs) [236]. The high concentration of glucose led to increased formation of foam cells in macrophage [240]. In a vitro study curcumin $(10 \mu \mathrm{m} / \mathrm{L})$ via activated protein-1 (AP-1-a transcription factor [241]) inhibition appeared to suppress the formation of macrophage-derived foam cells stimulated with high glucose levels via the LOX-1-dependent pathway [236]. Curcumin $(5 \mu \mathrm{m} / \mathrm{L})$ can prevent macrophages via LXR $\alpha$ dependent AMPK-signalling pathways in the human THP-1 cell line from being transformed into foam cells leading to the prevention of atherosclerosis [165]. 
Table 1. Summary of curcumin human intervention studies.

\begin{tabular}{|c|c|c|c|c|c|c|}
\hline Dose & Design & Subjects & Period & Effects & No Effects & Ref \\
\hline $\begin{array}{l}1 \mathrm{~g} / \text { day of curcuminoids (curcumin C3 } \\
\text { Complex®Sami Labs LTD, Bangalore, } \\
\text { Karnataka, India) combined with } 10 \\
\mathrm{mg} / \text { day of piperine }\end{array}$ & $\begin{array}{l}\text { randomised } \\
\text { double-blind, } \\
\text { placebo-controlled }\end{array}$ & $\begin{array}{l}100 \text { subjects with T2DM aged } \\
18-65 \text { years }\end{array}$ & 12 weeks & $\begin{array}{l}\downarrow \text { body weight, } \downarrow \text { BMI, } \downarrow \text { TC, } \\
\downarrow \text { Lp(a), } \uparrow \text { HDL-C compared } \\
\text { with the placebo }\end{array}$ & $\begin{array}{l}\text { TG, LDL-C compared with } \\
\text { the placebo }\end{array}$ & Panahi et al. 2017 [45] \\
\hline $\begin{array}{l}800 \mathrm{mg} \times 2 / \text { day of curcumin-based } \\
\text { product (enteric-coated and containing } \\
800 \mathrm{mg} / \text { dose } / \text { die of } 95 \% \text { curcumin } \\
\text { complexed with } 20 \% \text { phosphatidylserine } \\
\text { and blended with } 8 \mathrm{mg} / \text { dose/die of } \\
\text { piperine) }+ \text { lifestyle intervention, or } 400 \\
\mathrm{mg} \times 2 \text { day of phosphatidylserine }+ \\
\text { lifestyle intervention }\end{array}$ & randomised parallel & $\begin{array}{l}44 \text { overweight subjects with } \\
\text { metabolic syndrome (mean } \\
\text { BMI } 25-29.9 \mathrm{~kg} / \mathrm{m}^{2} ; \text { mean age } \\
39.1 \pm 16.8 \text { years) }\end{array}$ & 4 weeks & $\begin{array}{l}\downarrow \text { body weight, } \downarrow \text { body fat, } \\
\downarrow \text { waistline, } \downarrow \text { BMI compared } \\
\text { with the } \\
\text { phosphatidylserine group }\end{array}$ & & Di Pierro et al. 2015 [46] \\
\hline $\begin{array}{l}80 \mathrm{mg} / \text { day of nano- micelle curcumin } \\
\text { (SinaCurcumin®Exir Nano Sina Co., } \\
\text { Tehran, Tehran province, Iran) }\end{array}$ & $\begin{array}{l}\text { randomised, } \\
\text { double-blind, } \\
\text { placebo-controlled }\end{array}$ & $\begin{array}{l}70 \text { subjects with T2DM aged } \\
\text { over } 18 \text { years }\end{array}$ & 3 months & $\begin{array}{l}\downarrow \mathrm{HbA1}_{\mathrm{C}}, \downarrow \text { fasting blood } \\
\text { glucose, } \downarrow \text { BMI compared with } \\
\text { the placebo }\end{array}$ & $\begin{array}{l}\text { TC, LDL-C, HDL-C compared } \\
\text { with the placebo }\end{array}$ & Rahimi et al. 2016 [57] \\
\hline $\begin{array}{l}400 \mathrm{mg} / \text { day of Longvida }{ }^{\circledR} \\
\text { (containing } \sim 80 \mathrm{mg} \text { curcumin in a solid } \\
\text { lipid formulation) }\end{array}$ & $\begin{array}{l}\text { randomised, } \\
\text { double-blind, } \\
\text { placebo-controlled, } \\
\text { parallel }\end{array}$ & $\begin{array}{l}60 \text { elderly subjects (mean age: } \\
68.5 \text { years) }\end{array}$ & 4 weeks & $\begin{array}{l}\downarrow \mathrm{TC}, \downarrow \text { LDL-C, } \\
\uparrow \text { memory, } \uparrow \text { mood } \\
\text { compared with the placebo }\end{array}$ & & Cox et al. 2015 [68] \\
\hline $\begin{array}{l}80 \mathrm{mg} / \text { day of lipidated curcumin } \\
\text { (Longvida }{ }^{\circledR} \text { ) }\end{array}$ & & $\begin{array}{l}38 \text { healthy middle-aged } \\
\text { subjects ( } 40-60 \text { years old) }\end{array}$ & 4 weeks & & $\begin{array}{l}\text { TC, LDL, HDL-C, CRP, TG, } \\
\text { salivary amylase, salivary } \\
\text { radical scavenging capacities, } \\
\text { catalase, beta amyloid protein, } \\
\text { sICAM, myeloperoxidase, } \\
\text { nitric oxide, ALT }\end{array}$ & Disilvestro et al. 2012 [79] \\
\hline $500 \mathrm{mg} /$ day of curcumin & open uncontrolled & 14 subjects with T2DM & 15 days & & $\begin{array}{l}\text { fasting glucose, insulin, } \\
\text { C-peptide, TG, TC, HDL-C, } \\
\text { LDL-C, ALT, AST, BUN }\end{array}$ & Yang et al. 2015 [80] \\
\hline $\begin{array}{l}2.8 \mathrm{~g} / \text { day of turmeric }(\sim 112 \mathrm{mg} / \text { day } \\
\text { of curcumin) }\end{array}$ & $\begin{array}{l}\text { randomised, } \\
\text { double-blind, } \\
\text { placebo-controlled, } \\
\text { crossover }\end{array}$ & $\begin{array}{l}62 \text { overweight/obese women } \\
\text { aged over } 40-75 \text { years }[\text { mean } \\
\left.(\mathrm{BMI}) \geq 34.5 \pm 0.8 \mathrm{~kg} / \mathrm{m}^{2}\right] \\
\text { with } \mathrm{CRP}=8.05 \pm 1.33 \mathrm{mg} / \mathrm{L}\end{array}$ & 4 weeks & & $\begin{array}{l}\text { F2-iso-prostanes, oxidised } \\
\text { LDL-C, CRP, IL-6, IL-8, IL-10, } \\
\text { TNF } \alpha \text {, IFN } \gamma \text {, IL-1 } \beta, \text { IL-12p70, } \\
\text { glucose, body weight, } \\
\text { percent body fat, SBP, } \\
\text { augmentation index }\end{array}$ & Nieman et al. 2012 [81] \\
\hline $\begin{array}{l}1 \mathrm{~g} / \text { day of curcuminoids (500 } \mathrm{mg} \\
\text { C3Complex }{ }^{\circledR}+5 \mathrm{mg} \text { bioperine }{ }^{\circledR} \text { ) }\end{array}$ & $\begin{array}{l}\text { randomised } \\
\text { double-blind } \\
\text { placebo-controlled } \\
\text { crossover }\end{array}$ & $\begin{array}{l}30 \text { subjects aged } 18-65 \text { years } \\
\text { who were not taking } \\
\text { lipid-lowering agent, as well } \\
\text { as who had any conditions } \\
\text { including BMI } \geq 30 \mathrm{~kg} / \mathrm{m}^{2} \\
\text { or } 2 \text { risk factors (except for } \\
\text { T2DM) for CHD or } \geq 2 \text { risk } \\
\text { factors (except for T2DM) for } \\
\text { CHD and } 130 \mathrm{mg} / \mathrm{dL}< \\
\text { LDL-C }<160 \mathrm{mg} / \mathrm{dL}\end{array}$ & 30 days & $\begin{array}{l}\downarrow \text { TG compared with } \\
\text { the placebo }\end{array}$ & $\begin{array}{l}\text { LDL-C, HDL-C, CRP. body } \\
\text { weight, BMI, waist } \\
\text { circumference, arm } \\
\text { circumference, fat percentage }\end{array}$ & Mohammadi et al. 2013 [100 \\
\hline
\end{tabular}


Table 1. Cont.

\begin{tabular}{|c|c|c|c|c|c|c|}
\hline Dose & Design & Subjects & Period & Effects & No Effects & Ref \\
\hline $300 \mathrm{mg} /$ day of curcumin (NCB-02) & $\begin{array}{l}\text { randomised, } \\
\text { placebo-controlled, } \\
\text { parallel }\end{array}$ & $\begin{array}{l}67 \text { subjects with T2DM aged } \\
21-80 \text { years }\end{array}$ & 8 weeks & & $\begin{array}{l}\text { fasting glucose, } \mathrm{HbA1c}, \mathrm{TC}, \\
\text { LDL-C, HDL-C and TG } \\
\text { endothelial function, MDA, } \\
\text { ET-1, IL-6, TNF- } \alpha\end{array}$ & Usharani et al. 2008 [108] \\
\hline $\begin{array}{l}1 \mathrm{~g} / \text { day of curcuminoids ( } 500 \mathrm{mg} \\
\text { C3Complex }{ }^{\circledR}+5 \mathrm{mg} \text { bioperine }{ }^{\circledR} \text { ) }\end{array}$ & $\begin{array}{l}\text { randomised, } \\
\text { double-blind, } \\
\text { crossover }\end{array}$ & 30 obese subjects with $\mathrm{BMI} \geq 30$ & 4 weeks & $\begin{array}{l}\downarrow \text { IL- } 4, \downarrow \text { IL- } 1 \beta, \downarrow \text { VEGF } \\
\text { compared with the placebo }\end{array}$ & $\begin{array}{l}\text { IL-2, IL-6, IL-8, IL-10, IFN } \gamma \text {, } \\
\text { EGF, MCP-1 }\end{array}$ & Ganjali et al. 2014 [111] \\
\hline $1 \mathrm{~g} /$ day of curcumin & & $\begin{array}{l}117 \text { subjects with } \\
\text { metabolic syndrome }\end{array}$ & 8 weeks & $\begin{array}{l}\downarrow \text { TNF- } \alpha, \downarrow \text { IL- } 6, \downarrow \text { TGF- } \beta, \\
\downarrow \text { MCP- } 1 \text { compared } \\
\text { with placebo }\end{array}$ & & Panahi et al. 2016 [112] \\
\hline $\begin{array}{l}500 \mathrm{mg} / \text { day of an amorphous dispersion } \\
\text { curcumin formulation (comprising 70-mg } \\
\text { curcuminoids) }\end{array}$ & $\begin{array}{l}\text { randomised } \\
\text { double-blind, } \\
\text { placebo-controlled }\end{array}$ & $\begin{array}{l}77 \text { subjects with NAFLD } \\
(\text { mean age } 46.37 \pm 11.57 \text { years; } \\
\text { mean BMI } 31.35 \pm 5.67 \mathrm{~kg} / \mathrm{m}^{2} \text { ) }\end{array}$ & 8 weeks & $\begin{array}{l}\downarrow \text { glucose, } \downarrow \text { HbA1c, } \downarrow \text { TC, } \downarrow \\
\text { LDL, } \downarrow \text { TG, } \downarrow \text { liver fat, } \downarrow \text { BMI, } \\
\downarrow \text { AST, } \downarrow \text { ALT compared with } \\
\text { the placebo }\end{array}$ & & Rahmani et al. 2016 [134] \\
\hline $300 \mathrm{mg} /$ day of curcuminoids & $\begin{array}{l}\text { randomised } \\
\text { double-blind, } \\
\text { placebo-controlled }\end{array}$ & $\begin{array}{l}100 \text { overweight/obese subjects } \\
\text { with T2DM (average age: } \\
54.72 \pm 8.34 \text { years; BMI } \geq 24.0\end{array}$ & 12 weeks & $\begin{array}{l}\downarrow \text { fasting glucose, } \downarrow \text { HbA1c, } \downarrow \\
\text { HOMA-IR, } \downarrow \text { FFAs }, \downarrow \text { TG, } \uparrow \\
\text { LPL compared with a placebo }\end{array}$ & $\begin{array}{l}\text { TC, LDL- C, HDL- C, Apo A-I } \\
\text { or Apo B, body weight, waist } \\
\text { and hip circumferences }\end{array}$ & Na et al. 2013 [135] \\
\hline $1.5 \mathrm{~g} /$ day of curcuminoid & $\begin{array}{l}\text { randomised, } \\
\text { double-blind, } \\
\text { placebo-controlled }\end{array}$ & 237 prediabetic subjects & $3,6,9$ months & $\begin{array}{l}\downarrow \text { HbA1c, } \downarrow \text { fasting glucose, } \downarrow \\
\text { OGTT at } 3,6 \text {, and } 9 \text { months, } \downarrow \\
\text { diagnosis of T2DM, } \uparrow \\
\text { HOMA- } \beta \text { at } 6 \text { \& } 9 \text { months, } \uparrow \\
\text { adiponectin at } 9 \text { months, } \downarrow \\
\text { C-peptide at } 9 \text { months, } \downarrow \\
\text { insulin at } 9 \text { months, } \downarrow \text { body } \\
\text { weight at } 9 \text { month compared } \\
\text { with the placebo }\end{array}$ & $\begin{array}{l}\text { AST, ALT, creatinine, bone } \\
\text { mineral density, } \\
\text { waist circumference }\end{array}$ & Chuengsamarn et al. 2012 [136] \\
\hline $\begin{array}{l}1 \mathrm{~g} / \text { day of phospholipidated curcumin } \\
(n=40) \text { equivalent to } 200 \mathrm{mg} / \text { day of pure } \\
\text { curcumin, or } 1 \mathrm{~g} / \text { day of unformulated } \\
\text { curcumin }(n=40) \text {, or placebo }(n=40)\end{array}$ & $\begin{array}{l}\text { Randomised, } \\
\text { double-blind, } \\
\text { placebo-controlled }\end{array}$ & $\begin{array}{l}120 \text { subjects with metabolic } \\
\text { syndrome aged } 18-65 \text { years }\end{array}$ & 6 weeks & $\begin{array}{l}\uparrow \text { adiponectin in the } \\
\text { unformulated curcumin group } \\
\text { compared with the } \\
\text { curcumin-phospholipid } \\
\text { complex group or the } \\
\text { placebo group }\end{array}$ & $\begin{array}{l}\text { BMI, body weight, waist } \\
\text { circumference, fasting blood } \\
\text { glucose, fat }(\%) \text { compared with } \\
\text { a curcumin-phospholipid } \\
\text { complex group or } \\
\text { a placebo group }\end{array}$ & Salahshooh et al. 2017 [138] \\
\hline $750 \mathrm{mg} /$ day of curcuminoid & $\begin{array}{l}\text { randomised } \\
\text { double-blind, } \\
\text { placebo-controlled }\end{array}$ & $\begin{array}{l}\text { subjects with T2DM (mean } \\
\text { age } 59 \pm 10.6 \text { years; } n=107\end{array}$ & 6 months & $\begin{array}{l}\uparrow \text { adiponectin, } \downarrow \text { leptin, } \downarrow \text { PWV, } \\
\downarrow \text { HOMA-IR, } \downarrow \text { TG, } \downarrow \text { uric acid, } \\
\downarrow \text { visceral fat, } \downarrow \text { total body fat } \\
\text { compared with the placebo }\end{array}$ & & Chuengsamarn et al. 2014 [139] \\
\hline $2.8 \mathrm{~g} /$ day of turmeric & $\begin{array}{l}\text { randomised } \\
\text { crossover }\end{array}$ & $\begin{array}{l}11 \text { healthy subjects aged } \\
21-38 \text { years }\end{array}$ & 4 weeks & & fasting glucose, TC, TG & Tang et al. 2008 [140] \\
\hline
\end{tabular}


Table 1. Cont.

\begin{tabular}{|c|c|c|c|c|c|c|}
\hline Dose & Design & Subjects & Period & Effects & No Effects & Ref \\
\hline $6 \mathrm{~g}$ of curcuma C. longa (turmeric) & crossover, acute & $\begin{array}{l}14 \text { healthy subjects (mean age: } \\
29 \pm 1 \text { years, BMI: } 23.9 \pm \\
2.7 \mathrm{~kg} / \mathrm{m}^{2} \text { ) }\end{array}$ & & $\begin{array}{l}\uparrow \text { insulin responses compared } \\
\text { with the placebo }\end{array}$ & postprandial glucose responses & Wickenberg et al. 2010 [141] \\
\hline 500 and $750 \mathrm{mg} /$ day of curcumin & $\begin{array}{l}\text { randomised, } \\
\text { single-blind, } \\
\text { placebo-controlled }\end{array}$ & nondiabetic obese subjects & 12 weeks & & $\begin{array}{l}\text { BDNF, body weight, BMI, fat, } \\
\text { glucose, TC, LDL, TG, HDL-C, } \\
\text { VLDL, uric acid, oxLDL, } \\
\text { protein carbonyls }\end{array}$ & Franco-Robles et al. 2014 [142] \\
\hline $1890 \mathrm{mg} /$ day of curcumin extract & $\begin{array}{l}\text { randomised, } \\
\text { double-blind, } \\
\text { placebo-controlled }\end{array}$ & $\begin{array}{l}33 \text { subjects aged over } \\
40-60 \text { years with metabolic } \\
\text { syndrome }(\text { mean BMI: } \\
\left.30.06 \pm 4.12 \mathrm{~kg} / \mathrm{m}^{2}\right)\end{array}$ & 12 weeks & $\begin{array}{l}\downarrow \text { LDL-C } \\
\text { compared with the placebo }\end{array}$ & $\begin{array}{l}\text { weight, BMI, fasting glucose, } \\
\text { HbA1C, TG, TC, VLDL, } \\
\text { HDL-C, Non-HDL-C and } \\
\text { T-Chol/HDL-C ratio }\end{array}$ & Yang et al. 2014 [143] \\
\hline $2 \mathrm{~g} /$ day of curcumin (Longvida ${ }^{\circledR}$ ) & $\begin{array}{l}\text { double-blind, } \\
\text { parallel, } \\
\text { randomised }\end{array}$ & $\begin{array}{l}39 \text { healthy middle-aged and } \\
\text { older adults (45-74 years) }\end{array}$ & 12 weeks & Nil compared with placebo & $\begin{array}{l}\text { adiponectin, leptin, insulin, } \\
\text { HOMA-IR, oxidised LDL-C, } \\
\text { total antioxidant status, GPx, } \\
\text { IL-6, TNF- } \alpha, \text { cortisol, ET-1 } \\
\text { FMD resistance artery } \\
\text { endothelial function }\left(\mathrm{FBF}_{\mathrm{ACh}}\right)\end{array}$ & Santos-Parker et al. 2017 [144] \\
\hline $45-180 \mathrm{mg} /$ day of curcumin & $\begin{array}{l}\text { randomised } \\
\text { double-blind } \\
\text { controlled }\end{array}$ & $\begin{array}{l}75 \text { subjects with acute } \\
\text { coronary syndrome }\end{array}$ & 1 year & & $\begin{array}{l}\text { TC, LDL-C, HDL-C, TG, } \\
\text { fasting glucose, 2-hour glucose }\end{array}$ & Alwi et al. 2008 [145] \\
\hline $\begin{array}{l}1000 \mathrm{mg} / \text { day of curcumin + dietary and } \\
\text { lifestyle intervention }\end{array}$ & $\begin{array}{l}\text { Randomised, } \\
\text { placebo-controlled }\end{array}$ & 87 subjects with NAFLD & 8 weeks & $\begin{array}{l}\downarrow \text { TC, } \downarrow \text { non-HDL-C, } \downarrow \text { LDL-C, } \\
\downarrow \text { TG } \downarrow \text { uric acid compared } \\
\text { with the placebo. }\end{array}$ & $\begin{array}{l}\text { HbA1c, fasting glucose, insulin, } \\
\text { HOMA-IR, HOMA- } \beta \text {, } \\
\text { quantitative insulin sensitivity } \\
\text { check index (QUICKI) } \\
\text { compared with the placebo. } \\
\text { insulin, HOMA-IR, HOMA- } \beta \text {. } \\
\text { QUICKI within the group. }\end{array}$ & Panahi et al. 2016 [146] \\
\hline $4 \mathrm{~g} /$ day or $1 \mathrm{~g} /$ day of curcumin & $\begin{array}{l}\text { randomised, } \\
\text { double-blind, } \\
\text { placebo-controlled }\end{array}$ & $\begin{array}{l}36 \text { elderly subjects (mean age: } \\
73.4 \pm 8.8 \text { years) }\end{array}$ & $\begin{array}{l}\text { over } 1 \text { month } \\
\text { or } 6 \text { months }\end{array}$ & & TG, LDL-C, HDL-C & Baum et al. 2007 [160] \\
\hline $\begin{array}{l}200 \mathrm{mg} / \text { day of curcumin (Meriva } ® \text {, Indena } \\
\mathrm{SpA} \text {, Viale Ortles, Milan, Italy) }+2 \mathrm{~g} / \text { day of } \\
\text { phytosterols }(n=17) \text {, or } 200 \mathrm{mg} / \text { day of } \\
\text { curcumin }(n=18) \text {, or } 2 \mathrm{~g} / \text { day of } \\
\text { phytosterols }(n=17) \text {, or placebo }(n=18)\end{array}$ & $\begin{array}{l}\text { double-blind, } \\
\text { randomised, } \\
\text { placebo-controlled, } \\
2 \times 2 \text { factorial trial }\end{array}$ & $\begin{array}{l}70 \text { hypercholesterolemia } \\
\text { subjects (mean fasting TC: } \\
6.57 \pm 0.13 \mathrm{mM} / \mathrm{L} \text { ) aged } \\
18-70 \text { years }\end{array}$ & 4 weeks & $\begin{array}{l}\downarrow \mathrm{TC}, \downarrow \text { LDL-C and } \downarrow \text { TC: } \\
\text { HDL-C within phytosterol } \\
\text { group and within curcumin } \\
\text { plus phytosterol group. No } \\
\text { change with curcumin alone }\end{array}$ & & Ferguson et al. 2018 [161] \\
\hline
\end{tabular}


Table 1. Cont.

\begin{tabular}{|c|c|c|c|c|c|c|}
\hline Dose & Design & Subjects & Period & Effects & No Effects & Ref \\
\hline $\begin{array}{l}1000 \mathrm{mg} / \text { day of curcuminoids and piperine } \\
\text { (bioperine } \circledast \text { ) (100: } 1 \text { ratio combination) }\end{array}$ & $\begin{array}{l}\text { randomised } \\
\text { double-blind, } \\
\text { placebo-controlled } \\
\text { parallel }\end{array}$ & $\begin{array}{l}117 \text { subjects with metabolic } \\
\text { syndrome (aged } 25-75 \text { years) }\end{array}$ & 8 weeks & $\begin{array}{l}\downarrow \downarrow \text { LDL-C, } \downarrow \text { non-HDL-C, } \\
\downarrow \text { TC, } \downarrow \text { TG, } \downarrow \text { Lp(a), } \\
\uparrow \text { HDL-C } \\
\text { compared with the placebo }\end{array}$ & sdLDL & Panahi et al. 2014 [163] \\
\hline $\begin{array}{l}1 \mathrm{~g} / \text { day of curcuminoids ( } 500 \mathrm{mg} \\
\text { C3Complex® }+5 \mathrm{mg} \text { bioperine@ }{ }^{\circledR S a m i} \text { Labs } \\
\text { LTD, Bangalore, Karnataka, India) }\end{array}$ & $\begin{array}{l}\text { randomised, } \\
\text { double-blind, } \\
\text { placebo-controlled, } \\
\text { crossover }\end{array}$ & $\begin{array}{l}30 \text { obese subjects (mean BMI } \\
33.95 \pm 3.81 \text { ) }\end{array}$ & 30 days & & $\begin{array}{l}\text { BMI and weight compared } \\
\text { with the placebo }\end{array}$ & Esmaily et al. 2015 [186] \\
\hline $\begin{array}{l}50 \mathrm{mg} / \text { day of curcumin } \\
\text { ( } 250 \mathrm{mgCurcuWIN} \text { ) or } 200 \mathrm{mg} / \text { day of } \\
\text { curcumin ( } 1000 \mathrm{mg} \text { CurcuWIN) }\end{array}$ & $\begin{array}{l}\text { randomised } \\
\text { controlled } \\
\text { double-blind, } \\
\text { parallel }\end{array}$ & $\begin{array}{l}59 \text { healthy subjects aged } \\
19-29 \text { years }\end{array}$ & 8 weeks & $\begin{array}{l}200 \mathrm{mg} / \text { day of curcumin: } \uparrow \\
\text { endothelial function compared } \\
\text { with placebo }\end{array}$ & & Oliver et al. 2016 [237] \\
\hline
\end{tabular}

$\uparrow$-increased; $\downarrow$-decreased; ALT—alanine aminotransferase; AST—aspartate aminotransferase; BDNF-brain-derived neurotrophic factor; BMI-Body Mass Index; BUN-urea nitrogen; $\mathrm{CHD}$ - coronary heart disease; $\mathrm{CRP}-\mathrm{C}$ reactive protein; EGF—epidermal growth factor; ET-1—endothelin-1; FBFACh—forearm blood flow to brachial artery infusion of acetylcholine; FFAs—-free fatty acids; FMD—flow-mediated dilation; GPx—glutathione peroxidase; HbA1c—glycated haemoglobin; HDL- C-high-density lipoprotein cholesterol; HOMA-IR-homeostasis model assessment insulin resistance; LDL-C-low-density lipoprotein cholesterol; Lp(a)—lipoprotein a; LPL-lipoprotein lipase; LPS—lipopolysaccharides; MDA-Malondialdehyde; MCP-1 - monocyte chemoattractant protein 1; NAFLD—non-alcoholic fatty liver disease; Nrf2-nuclear factor erythroid 2-related factor 2; NQO1-NAD(P)H: quinone oxidoreductase; OGTT—oral glucose tolerance test; PWV—pulse wave velocity; QUICKI—quantitative insulin sensitivity check index; SBP—systolic blood pressure; sdLDL—small dense low density lipoprotein; SOD—superoxide dismutase; TBARS—-thiobarbituric acid reactive substances; TC—-total cholesterol; TG—-triglyceride; TGF- $\beta$-transforming growth factor beta; T2DM—type 2 diabetes mellitus; TNF- $\alpha$-tumor necrosis factor-alpha; VLDL—very low-density lipoprotein; VEGF-vascular endothelial growth factor. 
Early growth response-1 gene product (Egr-1) is a pathophysiological transcription factor which induces the activity of plasminogen activator inhibitor type-1 (PAI-1). Elevated PAI-1 is related to increased insulin resistance. Curcumin $(0-40 \mu \mathrm{m} / \mathrm{L})$ downregulated Egr-1 protein in HUVECs [235].

Reduced NO bioavailability (or reduced NO synthesis) is associated with endothelial dysfunction [242]. Studies [243-245] showed that curcumin upregulated eNOS to improve endothelial dysfunction in HUVECs when oxidative stress is induced by $\mathrm{H} 2 \mathrm{O} 2$ [244] in 2K-1C hypertensive rats [243] and in A10 vascular smooth muscle cells [245].

Curcumin has shown cardioprotective effects [246,247]. Curcumin treatment $(150 \mathrm{mg} / \mathrm{kg}$ or $100 \mu \mathrm{m} / \mathrm{L})$ of diabetic rat hearts decreased oxidative DNA and protein damage by decreasing levels of endothelial nitric oxide synthase (eNOS) and inducible nitric oxide synthase (iNOS) via reduced NF-kB and AP-11 in both diabetic rat hearts and in microvascular endothelial cells induced by high glucose. [246]. A vasoconstrictor, ET-1 levels increased with curcumin treatment in diabetic rat hearts and microvascular endothelial cells but ET-1 levels in the kidneys and the retina decreased, indicating that curcumin acts differently on organs [246].

Curcumin treatment $(5,10$ and $30 \mu \mathrm{m} / \mathrm{L})$ inhibited inflammatory cytokines (MCP-1, TNF- $\alpha$, toll-like receptors (TLRs) and iNOS) and NO generation in vascular smooth muscle cells of rats treated with LPS through the downregulation of TLR4-MAPK/NF-kB pathways related with NADPH-mediated intracellular ROS generation [248].

\subsection{Neurodegenerative Diseases}

Diabetes mellitus enhances the risk of dementia. The impairments in glucose metabolism, insulin signalling, insulin sensitivity and lipid metabolism, as well as increases in inflammation and oxidative stress in central nerve and peripheral system, contribute to the risk of Alzheimer's disease (AD) [249-252].

The etiology of AD includes accumulation of fibrillar amyloid- $\beta(\mathrm{A} \beta)$ peptides (amyloid plaques), decreased $A \beta$ degradation enzymes, $A \beta$ oligomer-promoted synaptic dysfunction, neurotoxic mediators from glial cells, apoE4 (lipid transport protein)-enhanced A $\beta$ deposits, impaired mitochondrial function, mis-localised tau protein from axons to neuronal soma and dendrites, increased neurofibrillary tangles (NFTs - comprised of hyperphosphorylated tau) formation, self-assembled $\alpha$-synuclein, vascular abnormalities, impaired supply of nutrients, impaired metabolic by-product removals, as well as activated glial cells [252]. Loss of neurons in certain brain areas such as pyramidal cells in lamina II of the entorhinal cortex and in the CA1 region of the hippocampus are responsible for early AD pathology $[253,254]$.

Moreover, the accumulation of advanced glycation end products (AGEs) and the receptor for advanced glycation end products (RAGE) are associated with the T2DM, CVD, degenerative disease and ageing [255-258]. The increased AGE binding to microglia, neurons and vascular endothelia cells stimulates inflammatory actions and $A \beta$ influx, which in turn leads to neuronal disfunction, cognitive decline and brain damage $[259,260]$.

$A \beta$ oligomers in cultured hippocampal neurons lead to phosphorylation of tau and inhibition of IRS-1 (Ser616) through the activation of c-Jun N-terminal kinase signalling, while curcumin treatment of triple transgenic -AD mice on a high-fat diet showed reductions in phosphorylated JNK, IRS-1, and tau in their brain [261].

Islet amyloid polypeptide (IAPP) or amylin is a hormone consisting of 37 amino acid residues which is co-released with insulin from pancreatic $\beta$ cells [262]. The accumulation of amyloid as a consequence of the IAPP misfolding is associated with T2DM, AD and Parkinson's disease [263,264]. Curcumin inhibited the self-assembly of IAPP $[265,266]$.

In the hippocampal CA1 area of the brain of AD mice (PS1dE9 double transgenic mice model), curcumin upregulated the expressions of GLUT1 and GLUT3 indicating an improvement in cerebral glucose uptake. Curcumin also stimulated insulin-like growth factor (IGF)-1R, IRS-2, phosphoinositide 3-kinase (PI3K), p-PI3K, Akt and p-Akt protein, and suppressed IR and IRS-1 which implicates the improvement in insulin signalling pathways [267]. In addition, curcumin enhanced spatial memory and learning as assessed by the water maze behaviour test [268]. A $\beta$-derived diffusible ligands (ADDLs) are known to dysfunction insulin signalling [269-271] and act as neurotoxins [272] in AD. 
Curcumin treatment showed decreases in $\mathrm{A} \beta 40, \mathrm{~A} \beta 42$, ADDLs and $\gamma$-secretase [presenilin (PS2)] expression, as well as increases in $A \beta$ degradation enzymes such as insulin-degrading enzymes and neprilysin in the hippocampus CA1 region. The changes in these molecules are related with improved behaviour functions [268].

A recent RCT indicated that curcumin could reduce amyloid and tau accumulation in a certain brain region leading to the improvement memory and attention. Non-demented adults (aged $51-84$ years; $n=21$ ) who ingested curcumin (Theracurmin ${ }^{\circledR}$ containing $90 \mathrm{mg}$ of curcumin twice daily) for 18 months showed the enhanced memory and attention compared with a placebo. Amyloid and tau accumulation on brain were assessed by 2-(1-[71] ethylidene)malononitrile positron emission tomography (FDDNP-PET). Curcumin significantly lowered FDDNP binding in the amygdala (ES $=-0.41, p=0.04$ ) compared with a placebo $(\mathrm{ES}=0.08, p=0.6$; between-group: $\mathrm{ES}=0.48, p=0.07)$ [71]

An AD brain shows an overexpression of PI3K/Akt/mTOR signalling, which is associated with insulin resistance and the pathology of $A \beta$ and tau [273,274]. Curcumin decreased cognitive impairment as assessed by Morris water maze test, inhibited A $\beta$ generation, and suppressed PI3K, phosphorylated Akt and mammalian target of rapamycin (mTOR-Akt regulating cell growth, proliferation, survival, angiogenesis, as well as autophagy [275]) leading to stimulated autophagy, in APP/PS1 double transgenic mice (an AD mice model) [276].

The modification of synapse structure and function is associated with the development of AD. The decreases in synapse-related proteins, including PSD95 and Shank1, contribute to the pathology of AD. Curcumin treatment improved the quantity and structure of the synapse by facilitating the PSD95 and Shank1 in the hippocampal CA1 regions of the APPswe/PS1dE9 double transgenic mice [277]. Curcumin treatment improved synaptic plasticity and neurogenesis resulting in improved memory function [278-280].

Brain-derived neurotrophic factor (BDNF) is a protein which stimulates neurogenesis, synaptic plasticity and memory in hippocampus and frontal cortex (FC) [281]. Decreased levels of BDNF are reported in obese and diabetic conditions [282-285]. Franco-Robles et al. 2014 [142] conducted both animal and human studies to investigate effects of curcumin on BDNF levels in the hippocampus and $\mathrm{FC}$ of diabetic $\mathrm{db} / \mathrm{db}$ mice and in sera of obese subjects. Compared to baseline, curcumin treatment (50 mg/kg daily) for 8 weeks normalised BDNF levels in the hippocampus and FC of diabetic $\mathrm{db} / \mathrm{db}$ mice. However, nondiabetic obese human subjects who consumed curcumin (500 and $750 \mathrm{mg} /$ day) for 12 weeks did not have altered BDNF levels. Curcumin $(500 \mathrm{mg})$ significantly decreased LDL-C in weeks 2 and 12. Curcumin (500 mg) in weeks 6 and 12 significantly decreased TBARS and oxLDL. Curcumin (500 mg and $750 \mathrm{mg}$ ) significantly lowered protein carbonyls levels in week 2,6 and 12 . Curcumin (500 mg and $750 \mathrm{mg}$ ) did not alter body weight, BMI, fat, glucose, TC, TG, HDL-C, VLDL and uric acid during the study period [142].

Membrane integrity is important to mainting the normal function of mitochondria and synapse in brain [286,287]. Curcumin facilitated the DHA biosynthesis in liver and DHA accumulation in the brain indicating that curcumin $(1-10,20$, or $40 \mu \mathrm{m} / \mathrm{L})$ can improve cell membrane integrity in the brain, consequently leading to the improvement of neurodegenerative disease by enhancing mitochondria and synaptic function [288,289].

Inflammation is a key player in the development of neurodegenerative diseases [290]. Microglial cells are resident macrophages that play a crucial role in innate immune regulation and brain homeostasis [291-293]. COXs participate in PGs formation [294]. The expression of COXs occurs when microglial cells and astrocytes are stimulated by inflammation [295]. Curcumin treatment (4-20 $\mathrm{m} / \mathrm{L})$ inhibited LPS-activated COX-2 gene expression and pro-inflammatory cytokines through the suppression of NF-kB and Activator Protein 1 (AP-1) in BV2 microglial cell [296,297]. Curcumin treatment $(20 \mu \mathrm{m} / \mathrm{L})$ suppressed migration of microglia in LPS-activated BV-2 cells with the inhibition of IL-4, PPAR- $\alpha$, TLR 2, Prostaglandin-endoperoxide synthase 2 and NO synthase 2, indicating an anti-inflammatory and neuroprotective effects of curcumin [298]. 


\section{Conclusions}

A summary of possible mechanisms of curcumin on glucose homeostasis, lipid metabolism, oxidative stress, inflammation and endothelial function is shown in Figure 2.

In conclusion, based on high-dose animal and in vitro studies, curcumin appears to be a promising therapeutic agent to decrease the risk of T2DM, CVD and neurodegenerative disease by improving glucose homeostasis, lipid metabolism, endothelial function and insulin signalling, and by inhibiting $A \beta$ aggregation. These favourable effects of curcumin could be attributable to potent anti-oxidant and anti-inflammatory actions.

To avoid misinterpretation of results from in vitro studies, it should be noted that cells used in most of the in vitro studies were exposed to very high level of curcumin, i.e., 10 to 100 times greater than the circulating dose measured in plasma after consumption of curcumin supplements or curcumin-rich meal.

There is variability in curcumin metabolism between humans and animals. Thus, the results of in vitro and animal studies cannot be directly related to human physiology. The formula to convert animal doses into human doses for the determination of the equivalents of animal doses in human doses is as follows: human effective dose $(\mathrm{mg} / \mathrm{kg}$ body weight $)=$ animal dose $(\mathrm{mg} / \mathrm{kg}) \mathrm{X}$ animal $\mathrm{km} /$ human $\mathrm{km}$. The correction factor $(\mathrm{km})$ is calculated by dividing the average body weight $(\mathrm{kg})$ of species to its body surface area $\left(\mathrm{m}^{2}\right)$ [299]. Frequently, animal doses are well beyond normal human doses.

Curcumin is metabolised to curcumin glucuronide or curcumin sulphate by glucuronidase and sulfatase, respectively. The predominant curcumin glucuronides metabolites are terahydrocurcumin (THC) and hexahydrocurcumin (HHC). The minor curcumin metabolites are dihydroferulic acid and ferulic acid. These water-soluble metabolites are excreted through the urine [30]. Ninety-nine percent of plasma curcumin is glucuronide-conjugates. The maximum plasma concentrations of curcuminoid conjugates were observed within $1 \mathrm{~h}$ of oral administration in humans [25]. It is unclear whether curcumin metabolites are more or less bioactive than native curcumin [30,300-302].

Human studies at present are relatively unconvincing. So far, new curcumin formulations have been tested to assess an increase in bioavailability and efficacy in animal studies. A few clinical interventions have been conducted to see if the increased bioavailability with the new curcumin formulations is associated with cardiometabolic benefit, but no direct comparisons have been made with standard formulations. 


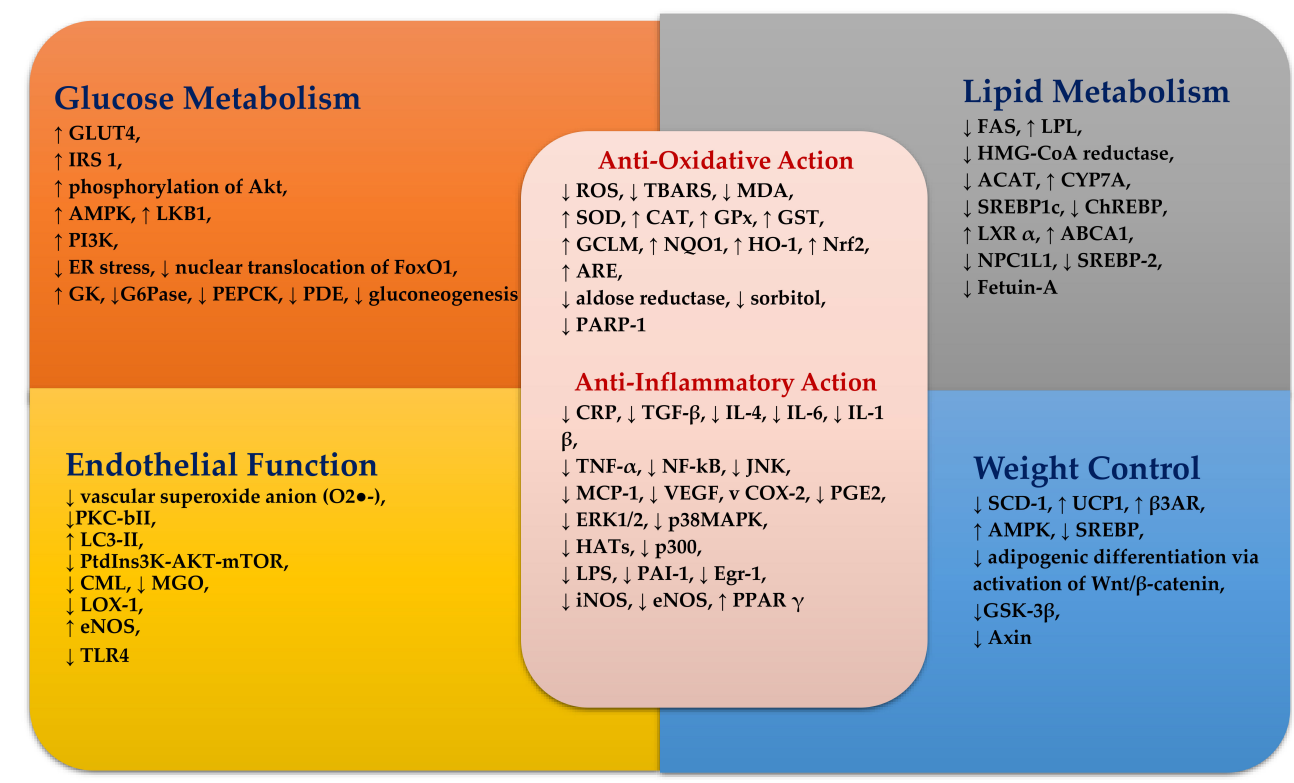

Figure 2. The summary of potential mechanisms linking curcumin metabolites to improved glucose, lipid metabolism, antioxidative action, anti-inflammatory action and endothelial function. Refer to the text for more details. $\uparrow$ —increase; $\downarrow$-decrease; ABCA1—ATP-binding cassette A1; ACAT—acyl-CoA cholesterol acyltransferase; Akt—serine/threonine kinase; AMPK— $5^{\prime}$ adenosine monophosphate-activated protein kinase; ARE-antioxidant-responsive element; $\beta 3 \mathrm{AR}-\beta 3$-adrenergic receptor; CAT—catalase; ChREBP—carbohydrate response element-binding protein; $\mathrm{CML}-\mathrm{N} \varepsilon$-(carboxymethyl) lysine; COX-2—cyclo-oxygenase 2; CRP-C-reactive protein; CYP7A — cholesterol $7 \alpha$-hydroxylase; Egr-1—early growth response-1 gene product; eNOS — endothelial nitric oxide synthase; ER — endoplasmic reticulum; ERK1/2 - extracellular signal-regulated protein kinases 1 and 2; FAS—fatty acid synthase; FOXO1—forkhead box protein O1; GCLM— $\gamma$-glutamyl-cysteine ligase; G6Pase—glucose-6-phosphatase;

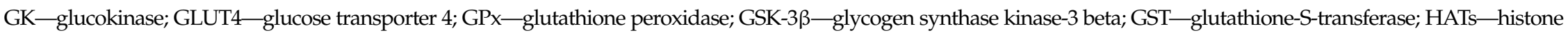
acetylases; HMG-CoA reductase-3-Hydroxy-3-methylglutaryl-coenzyme A reductase; HO-1-heme oxygenase1; IL—interleukin; iNOS-inducible nitric oxide synthase; IRS1-insulin receptor substrate-1; JNK-Jun NH2-terminal kinase; LKB1-serine-threonine liver kinase B1; LOX-1-lectin-like oxidised LDL receptor; LPL—lipoprotein lipase; LPS—lipopolysaccharides; LXR $\alpha$-liver X receptor alpha; MAPK—-mitogen-activated protein kinase; MCP-1—monocyte chemoattractant protein 1; MDA - malondialdehyde; MGO-methylglyoxal; NF-kB - nuclear factor kappa B; mTOR - mammalian target of rapamycin; Nrf2-nuclear factor erythroid 2-related factor 2; NQO1-NAD(P)H dehydrogenase [quinone] 1; NPC1L1—Niemann-Pick C1 Like 1; PAI-1—plasminogen activator inhibitor type -1; PARP-1—poly ADP-ribose polymerase-1; PDE—-phosphodiesterase; PEPCK—phosphoenolpyruvate carboxykinase; PGE2—prostaglandin E2; PI3K—phosphoinositide 3-kinase; PKC-Bii—protein kinase C; PPAR — peroxisome proliferator-activated receptor; ROS—reactive oxygen species; SCD-1—stearoyl-coenzyme A desaturase 1; SOD—superoxide dismutase; SREBP1c—sterol regulatory element-binding protein 1c; TBARS—-thiobarbituric acid reactive substances; TGF- $\beta$-transforming growth factor beta; TLR4 — toll-like receptors 4; TNF $\alpha$-tumor necrosis factor $\alpha$; UCP1—uncoupling protein 1; VEGF—vascular endothelial growth factor. 
Author Contributions: All authors conceived of the manuscript structure and contributed to the writing and editing.

Funding: This research received no external funding.

Acknowledgments: Peter Clifton is supported by a NHMRC Principal Research Fellowship.

Conflicts of Interest: The authors declare no conflict of interest related to this manuscript.

\section{References}

1. Mancini, G.B.; Cheng, A.Y.; Connelly, K.; Fitchett, D.; Goldenberg, R.; Goodman, S.G.; Leiter, L.A.; Lonn, E.; Paty, B.; Poirier, P.; et al. Diabetes for cardiologists: Practical issues in diagnosis and management. Can. J. Cardiol. 2017, 33, 366-377. [CrossRef] [PubMed]

2. Pessin, J.E.; Saltiel, A.R. Signaling pathways in insulin action: Molecular targets of insulin resistance. J. Clin. Investig. 2000, 106, 165-169. [CrossRef] [PubMed]

3. Stumvoll, M.; Goldstein, B.J.; van Haeften, T.W. Type 2 diabetes: Principles of pathogenesis and therapy. Lancet 2005, 365, 1333-1346. [CrossRef]

4. Cho, N.H.; Shaw, J.E.; Karuranga, S.; Huang, Y.; da Rocha Fernandes, J.D.; Ohlrogge, A.W.; Malanda, B. Idf diabetes atlas: Global estimates of diabetes prevalence for 2017 and projections for 2045. Diabetes Res. Clin. Pract. 2018, 138, 271-281. [CrossRef] [PubMed]

5. Bommer, C.; Heesemann, E.; Sagalova, V.; Manne-Goehler, J.; Atun, R.; Barnighausen, T.; Vollmer, S. The global economic burden of diabetes in adults aged 20-79 years: A cost-of-illness study. Lancet Diabetes Endocrinol. 2017, 5, 423-430. [CrossRef]

6. Thomas, T.; Pfeiffer, A.F. Foods for the prevention of diabetes: How do they work? Diabetes Metab. Res. Rev. 2012, 28, 25-49. [CrossRef] [PubMed]

7. Xiao, J.B.; Hogger, P. Dietary polyphenols and type 2 diabetes: Current insights and future perspectives. Curr. Med. Chem. 2015, 22, 23-38. [CrossRef] [PubMed]

8. Hanhineva, K.; Torronen, R.; Bondia-Pons, I.; Pekkinen, J.; Kolehmainen, M.; Mykkanen, H.; Poutanen, K. Impact of dietary polyphenols on carbohydrate metabolism. Int. J. Mol. Sci. 2010, 11, 1365-1402. [CrossRef] [PubMed]

9. Williamson, G. Possible effects of dietary polyphenols on sugar absorption and digestion. Mol. Nutr. Food Res. 2013, 57, 48-57. [CrossRef] [PubMed]

10. Kim, Y.; Keogh, J.B.; Clifton, P.M. Polyphenols and glycemic control. Nutrients 2016, 8, 17. [CrossRef] [PubMed]

11. Lestari, M.L.; Indrayanto, G. Curcumin. Profiles Drug Subst. Excip. Relat. Methodol. 2014, 39, 113-204. [PubMed]

12. Ammon, H.P.; Wahl, M.A. Pharmacology of Curcuma longa. Planta Med. 1991, 57, 1-7. [CrossRef] [PubMed]

13. Gupta, S.C.; Sung, B.; Kim, J.H.; Prasad, S.; Li, S.; Aggarwal, B.B. Multitargeting by turmeric, the golden spice: From kitchen to clinic. Mol. Nutr. Food Res. 2013, 57, 1510-1528. [CrossRef] [PubMed]

14. Gupta, S.C.; Patchva, S.; Koh, W.; Aggarwal, B.B. Discovery of curcumin, a component of golden spice, and its miraculous biological activities. Clin. Exp. Pharmacol. Physiol. 2012, 39, 283-299. [CrossRef] [PubMed]

15. Jurenka, J.S. Anti-inflammatory properties of curcumin, a major constituent of Curcuma longa: A review of preclinical and clinical research. Altern. Med. Rev. 2009, 14, 141-153. [PubMed]

16. Wang, Y.J.; Pan, M.H.; Cheng, A.L.; Lin, L.I.; Ho, Y.S.; Hsieh, C.Y.; Lin, J.K. Stability of curcumin in buffer solutions and characterization of its degradation products. J. Pharm. Biomed. Anal. 1997, 15, 1867-1876. [CrossRef]

17. Gupta, S.C.; Kismali, G.; Aggarwal, B.B. Curcumin, a component of turmeric: From farm to pharmacy. BioFactors 2013, 39, 2-13. [CrossRef] [PubMed]

18. Kocaadam, B.; Sanlier, N. Curcumin, an active component of turmeric (Curcuma longa), and its effects on health. Crit. Rev. Food Sci. Nutr. 2017, 57, 2889-2895. [CrossRef] [PubMed]

19. Lao, C.D.; Ruffin, M.T.T.; Normolle, D.; Heath, D.D.; Murray, S.I.; Bailey, J.M.; Boggs, M.E.; Crowell, J.; Rock, C.L.; Brenner, D.E. Dose escalation of a curcuminoid formulation. BMC Complement. Altern. Med. 2006, 6, 10. [CrossRef] [PubMed] 
20. Sharma, R.A.; Euden, S.A.; Platton, S.L.; Cooke, D.N.; Shafayat, A.; Hewitt, H.R.; Marczylo, T.H.; Morgan, B.; Hemingway, D.; Plummer, S.M.; et al. Phase I clinical trial of oral curcumin: Biomarkers of systemic activity and compliance. Clin. Cancer Res. 2004, 10, 6847-6854. [CrossRef] [PubMed]

21. Bahramsoltani, R.; Rahimi, R.; Farzaei, M.H. Pharmacokinetic interactions of curcuminoids with conventional drugs: A review. J. Ethnopharmacol. 2017, 209, 1-12. [CrossRef] [PubMed]

22. Cheng, A.L.; Hsu, C.H.; Lin, J.K.; Hsu, M.M.; Ho, Y.F.; Shen, T.S.; Ko, J.Y.; Lin, J.T.; Lin, B.R.; Ming-Shiang, W.; et al. Phase I clinical trial of curcumin, a chemopreventive agent, in patients with high-risk or pre-malignant lesions. Anticancer Res. 2001, 21, 2895-2900. [PubMed]

23. Garcea, G.; Jones, D.J.; Singh, R.; Dennison, A.R.; Farmer, P.B.; Sharma, R.A.; Steward, W.P.; Gescher, A.J.; Berry, D.P. Detection of curcumin and its metabolites in hepatic tissue and portal blood of patients following oral administration. Br. J. Cancer 2004, 90, 1011-1015. [CrossRef] [PubMed]

24. Garcea, G.; Berry, D.P.; Jones, D.J.; Singh, R.; Dennison, A.R.; Farmer, P.B.; Sharma, R.A.; Steward, W.P.; Gescher, A.J. Consumption of the putative chemopreventive agent curcumin by cancer patients: Assessment of curcumin levels in the colorectum and their pharmacodynamic consequences. Cancer Epidemiol. Biomark. Prev. 2005, 14, 120-125.

25. Vareed, S.K.; Kakarala, M.; Ruffin, M.T.; Crowell, J.A.; Normolle, D.P.; Djuric, Z.; Brenner, D.E. Pharmacokinetics of curcumin conjugate metabolites in healthy human subjects. Cancer Epidemiol. Biomark. Prev. 2008, 17, 1411-1417. [CrossRef] [PubMed]

26. Shoba, G.; Joy, D.; Joseph, T.; Majeed, M.; Rajendran, R.; Srinivas, P.S. Influence of piperine on the pharmacokinetics of curcumin in animals and human volunteers. Planta Med. 1998, 64, 353-356. [CrossRef] [PubMed]

27. Ringman, J.M.; Frautschy, S.A.; Teng, E.; Begum, A.N.; Bardens, J.; Beigi, M.; Gylys, K.H.; Badmaev, V.; Heath, D.D.; Apostolova, L.G.; et al. Oral curcumin for alzheimer's disease: Tolerability and efficacy in a 24-week randomized, double blind, placebo-controlled study. Alzheimer's Res. Ther. 2012, 4, 43. [CrossRef] [PubMed]

28. Carroll, R.E.; Benya, R.V.; Turgeon, D.K.; Vareed, S.; Neuman, M.; Rodriguez, L.; Kakarala, M.; Carpenter, P.M.; McLaren, C.; Meyskens, F.L., Jr.; et al. Phase Ila clinical trial of curcumin for the prevention of colorectal neoplasia. Cancer Prev. Res. 2011, 4, 354-364. [CrossRef] [PubMed]

29. Kanai, M.; Yoshimura, K.; Asada, M.; Imaizumi, A.; Suzuki, C.; Matsumoto, S.; Nishimura, T.; Mori, Y.; Masui, T.; Kawaguchi, Y.; et al. A phase I/II study of gemcitabine-based chemotherapy plus curcumin for patients with gemcitabine-resistant pancreatic cancer. Cancer Chemother. Pharmacol. 2011, 68, 157-164. [CrossRef] [PubMed]

30. Anand, P.; Kunnumakkara, A.B.; Newman, R.A.; Aggarwal, B.B. Bioavailability of curcumin: Problems and promises. Mol. Pharm. 2007, 4, 807-818. [CrossRef] [PubMed]

31. Metzler, M.; Pfeiffer, E.; Schulz, S.I.; Dempe, J.S. Curcumin uptake and metabolism. BioFactors 2013, 39, 14-20. [CrossRef] [PubMed]

32. Burapan, S.; Kim, M.; Han, J. Curcuminoid demethylation as an alternative metabolism by human intestinal microbiota. J. Agric. Food Chem. 2017, 65, 3305-3310. [CrossRef] [PubMed]

33. Chiou, Y.-S.; Wu, J.-C.; Huang, Q.; Shahidi, F.; Wang, Y.-J.; Ho, C.-T.; Pan, M.-H. Metabolic and colonic microbiota transformation may enhance the bioactivities of dietary polyphenols. J. Funct. Foods 2014, 7, 3-25. [CrossRef]

34. Tan, S.; Calani, L.; Bresciani, L.; Dall'asta, M.; Faccini, A.; Augustin, M.A.; Gras, S.L.; Del Rio, D. The degradation of curcuminoids in a human faecal fermentation model. Int. J. Food Sci. Nutr. 2015, 66, 790-796. [CrossRef] [PubMed]

35. Hassaninasab, A.; Hashimoto, Y.; Tomita-Yokotani, K.; Kobayashi, M. Discovery of the curcumin metabolic pathway involving a unique enzyme in an intestinal microorganism. Proc. Natl. Acad. Sci. USA 2011, 108, 6615-6620. [CrossRef] [PubMed]

36. Tan, S.; Rupasinghe, T.W.; Tull, D.L.; Boughton, B.; Oliver, C.; McSweeny, C.; Gras, S.L.; Augustin, M.A. Degradation of curcuminoids by in vitro pure culture fermentation. J. Agric. Food Chem. 2014, 62, 11005-11015. [CrossRef] [PubMed]

37. Sehgal, A.; Kumar, M.; Jain, M.; Dhawan, D.K. Combined effects of curcumin and piperine in ameliorating benzo(a)pyrene induced DNA damage. Food Chem. Toxicol. 2011, 49, 3002-3006. [CrossRef] [PubMed]

38. Ghosh, M.; Singh, A.T.; Xu, W.; Sulchek, T.; Gordon, L.I.; Ryan, R.O. Curcumin nanodisks: Formulation and characterization. Nanomedicine 2011, 7, 162-167. [CrossRef] [PubMed] 
39. Song, L.; Shen, Y.; Hou, J.; Lei, L.; Guo, S.; Qian, C. Polymeric micelles for parenteral delivery of curcumin: Preparation, characterization and in vitro evaluation. Colloids Surf. A 2011, 390, 25-32. [CrossRef]

40. Mulik, R.S.; Monkkonen, J.; Juvonen, R.O.; Mahadik, K.R.; Paradkar, A.R. Transferrin mediated solid lipid nanoparticles containing curcumin: Enhanced in vitro anticancer activity by induction of apoptosis. Int. J. Pharm. 2010, 398, 190-203. [CrossRef] [PubMed]

41. Bansal, S.S.; Kausar, H.; Vadhanam, M.V.; Ravoori, S.; Gupta, R.C. Controlled systemic delivery by polymeric implants enhances tissue and plasma curcumin levels compared with oral administration. Eur. J. Pharm. Biopharm. 2012, 80, 571-577. [CrossRef] [PubMed]

42. Boruah, B.; Saikia, P.M.; Dutta, R.K. Binding and stabilization of curcumin by mixed chitosan-surfactant systems: A spectroscopic study. J. Photochem. Photobiol. A 2012, 245, 18-27. [CrossRef]

43. Ghalandarlaki, N.; Alizadeh, A.M. Nanotechnology-applied curcumin for different diseases therapy. BioMed Res. Int. 2014, 2014, 394264. [CrossRef] [PubMed]

44. Rahimi, H.R.; Nedaeinia, R.; Sepehri Shamloo, A.; Nikdoust, S.; Kazemi Oskuee, R. Novel delivery system for natural products: Nano-curcumin formulations. Avicenna J. Phytomed. 2016, 6, 383-398. [PubMed]

45. Panahi, Y.; Khalili, N.; Sahebi, E.; Namazi, S.; Reiner, Z.; Majeed, M.; Sahebkar, A. Curcuminoids modify lipid profile in type 2 diabetes mellitus: A randomized controlled trial. Complement. Ther. Med. 2017, 33, 1-5. [CrossRef] [PubMed]

46. Di Pierro, F.; Bressan, A.; Ranaldi, D.; Rapacioli, G.; Giacomelli, L.; Bertuccioli, A. Potential role of bioavailable curcumin in weight loss and omental adipose tissue decrease: Preliminary data of a randomized, controlled trial in overweight people with metabolic syndrome. Preliminary study. Eur. Rev. Med. Pharmacol. Sci. 2015, 19, 4195-4202. [PubMed]

47. Antony, B.; Merina, B.; Iyer, V.S.; Judy, N.; Lennertz, K.; Joyal, S. A pilot cross-over study to evaluate human oral bioavailability of BCM-95CG (biocurcumax), a novel bioenhanced preparation of curcumin. Indian J. Pharm. Sci. 2008, 70, 445-449. [CrossRef] [PubMed]

48. Comblain, F.; Sanchez, C.; Lesponne, I.; Balligand, M.; Serisier, S.; Henrotin, Y. Curcuminoids extract, hydrolyzed collagen and green tea extract synergically inhibit inflammatory and catabolic mediator's synthesis by normal bovine and osteoarthritic human chondrocytes in monolayer. PLoS ONE 2015, 10, e0121654. [CrossRef] [PubMed]

49. Mishra, S.; Narain, U.; Mishra, R.; Misra, K. Design, development and synthesis of mixed bioconjugates of piperic acid-glycine, curcumin-glycine/alanine and curcumin-glycine-piperic acid and their antibacterial and antifungal properties. Bioorg. Med. Chem. 2005, 13, 1477-1486. [CrossRef] [PubMed]

50. Maiti, K.; Mukherjee, K.; Gantait, A.; Saha, B.P.; Mukherjee, P.K. Curcumin-phospholipid complex: Preparation, therapeutic evaluation and pharmacokinetic study in rats. Int. J. Pharm. 2007, 330, 155-163. [CrossRef] [PubMed]

51. Jain, S.; Singh, P.; Mishra, V.; Vyas, S.P. Mannosylated niosomes as adjuvant-carrier system for oral genetic immunization against hepatitis B. Immunol. Lett. 2005, 101, 41-49. [CrossRef] [PubMed]

52. Aqil, F.; Munagala, R.; Jeyabalan, J.; Vadhanam, M.V. Bioavailability of phytochemicals and its enhancement by drug delivery systems. Cancer Lett. 2013, 334, 133-141. [CrossRef] [PubMed]

53. Ma, Z.; Haddadi, A.; Molavi, O.; Lavasanifar, A.; Lai, R.; Samuel, J. Micelles of poly(ethylene oxide)-bpoly(epsilon-caprolactone) as vehicles for the solubilization, stabilization, and controlled delivery of curcumin. J. Biomed. Mater. Res. Part A 2008, 86, 300-310. [CrossRef] [PubMed]

54. Yu, H.; Li, J.; Shi, K.; Huang, Q. Structure of modified epsilon-polylysine micelles and their application in improving cellular antioxidant activity of curcuminoids. Food Funct. 2011, 2, 373-380. [CrossRef] [PubMed]

55. Podaralla, S.; Averineni, R.; Alqahtani, M.; Perumal, O. Synthesis of novel biodegradable methoxy poly(ethylene glycol)-zein micelles for effective delivery of curcumin. Mol. Pharm. 2012, 9, 2778-2786. [CrossRef] [PubMed]

56. Song, Z.; Feng, R.; Sun, M.; Guo, C.; Gao, Y.; Li, L.; Zhai, G. Curcumin-loaded plga-peg-plga triblock copolymeric micelles: Preparation, pharmacokinetics and distribution in vivo. J. Colloid Interface Sci. 2011, 354, 116-123. [CrossRef] [PubMed]

57. Rahimi, H.R.; Mohammadpour, A.H.; Dastani, M.; Jaafari, M.R.; Abnous, K.; Ghayour Mobarhan, M.; Kazemi Oskuee, R. The effect of nano-curcumin on $\mathrm{HbA1c}$, fasting blood glucose, and lipid profile in diabetic subjects: A randomized clinical trial. Avicenna J. Phytomed. 2016, 6, 567-577. [PubMed]

58. Wu, W.; Shen, J.; Banerjee, P.; Zhou, S. Water-dispersible multifunctional hybrid nanogels for combined curcumin and photothermal therapy. Biomaterials 2011, 32, 598-609. [CrossRef] [PubMed] 
59. Karewicz, A.; Bielska, D.; Loboda, A.; Gzyl-Malcher, B.; Bednar, J.; Jozkowicz, A.; Dulak, J.; Nowakowska, M. Curcumin-containing liposomes stabilized by thin layers of chitosan derivatives. Colloids Surf. B Biointerfaces 2013, 109, 307-316. [CrossRef] [PubMed]

60. Zhang, J.; Tang, Q.; Xu, X.; Li, N. Development and evaluation of a novel phytosome-loaded chitosan microsphere system for curcumin delivery. Int. J. Pharm. 2013, 448, 168-174. [CrossRef] [PubMed]

61. Sindhu, K.; Indra, R.; Rajaram, A.; Sreeram, K.J.; Rajaram, R. Investigations on the interaction of gold-curcumin nanoparticles with human peripheral blood lymphocytes. J. Biomed. Nanotechnol. 2011, 7, 56. [CrossRef] [PubMed]

62. Omidfar, K.; Khorsand, F.; Darziani Azizi, M. New analytical applications of gold nanoparticles as label in antibody based sensors. Biosens. Bioelectron. 2013, 43, 336-347. [CrossRef] [PubMed]

63. Sweet, M.J.; Singleton, I. Silver nanoparticles: A microbial perspective. Adv. Appl. Microbiol. 2011, 77, 115-133. [PubMed]

64. Torne, S.; Darandale, S.; Vavia, P.; Trotta, F.; Cavalli, R. Cyclodextrin-based nanosponges: Effective nanocarrier for tamoxifen delivery. Pharm. Dev. Technol. 2013, 18, 619-625. [CrossRef] [PubMed]

65. Ramachandran, C.; Fonseca, H.B.; Jhabvala, P.; Escalon, E.A.; Melnick, S.J. Curcumin inhibits telomerase activity through human telomerase reverse transcritpase in MCF-7 breast cancer cell line. Cancer Lett. 2002, 184, 1-6. [CrossRef]

66. Ekambaram, P.; Abdul, H.S. Formulation and evaluation of solid lipid nanoparticles of ramipril. J. Young Pharm. 2011, 3, 216-220. [CrossRef] [PubMed]

67. Begum, A.N.; Jones, M.R.; Lim, G.P.; Morihara, T.; Kim, P.; Heath, D.D.; Rock, C.L.; Pruitt, M.A.; Yang, F.; Hudspeth, B.; et al. Curcumin structure-function, bioavailability, and efficacy in models of neuroinflammation and Alzheimer's disease. J. Pharmacol. Exp. Ther. 2008, 326, 196-208. [CrossRef] [PubMed]

68. Cox, K.H.; Pipingas, A.; Scholey, A.B. Investigation of the effects of solid lipid curcumin on cognition and mood in a healthy older population. J. Psychopharmacol. 2015, 29, 642-651. [CrossRef] [PubMed]

69. Zhou, H.; Wu, X.; Xu, W.; Yang, J.; Yang, Q. Fluorescence enhancement of the silver nanoparticalesCurcumin-cetyltrimethylammonium bromide-nucleic acids system and its analytical application. J. Fluoresc. 2010, 20, 843-850. [CrossRef] [PubMed]

70. Kanai, M.; Imaizumi, A.; Otsuka, Y.; Sasaki, H.; Hashiguchi, M.; Tsujiko, K.; Matsumoto, S.; Ishiguro, H.; Chiba, T. Dose-escalation and pharmacokinetic study of nanoparticle curcumin, a potential anticancer agent with improved bioavailability, in healthy human volunteers. Cancer Chemother. Pharmacol. 2012, 69, 65-70. [CrossRef] [PubMed]

71. Small, G.W.; Siddarth, P.; Li, Z.; Miller, K.J.; Ercoli, L.; Emerson, N.D.; Martinez, J.; Wong, K.P.; Liu, J.; Merrill, D.A.; et al. Memory and brain amyloid and tau effects of a bioavailable form of curcumin in non-demented adults: A double-blind, placebo-controlled 18-month trial. Am. J. Geriatr. Psychiatry 2018, 26, 266-277. [CrossRef] [PubMed]

72. Durackova, Z. Some current insights into oxidative stress. Physiol. Res. 2010, 59, 459-469. [PubMed]

73. Giacco, F.; Brownlee, M. Oxidative stress and diabetic complications. Circ. Res. 2010, 107, 1058-1070. [CrossRef] [PubMed]

74. Akash, M.S.; Rehman, K.; Chen, S. Role of inflammatory mechanisms in pathogenesis of type 2 diabetes mellitus. J. Cell. Biochem. 2013, 114, 525-531. [CrossRef] [PubMed]

75. Lontchi-Yimagou, E.; Sobngwi, E.; Matsha, T.E.; Kengne, A.P. Diabetes mellitus and inflammation. Curr. Diabetes Rep. 2013, 13, 435-444. [CrossRef] [PubMed]

76. Rehman, K.; Akash, M. Mechanisms of inflammatory responses and development of insulin resistance: How are they interlinked? J. Biomed. Sci. 2016, 23, 87. [CrossRef] [PubMed]

77. Reuter, S.; Gupta, S.C.; Chaturvedi, M.M.; Aggarwal, B.B. Oxidative stress, inflammation, and cancer: How are they linked? Free Radic. Biol. Med. 2010, 49, 1603-1616. [CrossRef] [PubMed]

78. Priyadarsini, K.I.; Maity, D.K.; Naik, G.H.; Kumar, M.S.; Unnikrishnan, M.K.; Satav, J.G.; Mohan, H. Role of phenolic $\mathrm{O}-\mathrm{H}$ and methylene hydrogen on the free radical reactions and antioxidant activity of curcumin. Free Radic. Biol. Med. 2003, 35, 475-484. [CrossRef]

79. DiSilvestro, R.A.; Joseph, E.; Zhao, S.; Bomser, J. Diverse effects of a low dose supplement of lipidated curcumin in healthy middle aged people. Nutr. J. 2012, 11, 79. [CrossRef] [PubMed]

80. Yang, H.; Xu, W.; Zhou, Z.; Liu, J.; Li, X.; Chen, L.; Weng, J.; Yu, Z. Curcumin attenuates urinary excretion of albumin in type II diabetic patients with enhancing nuclear factor erythroid-derived 2-like 2 (Nrf2) 
system and repressing inflammatory signaling efficacies. Exp. Clin. Endocrinol. Diabetes 2015, 123, 360-367. [CrossRef] [PubMed]

81. Nieman, D.C.; Cialdella-Kam, L.; Knab, A.M.; Shanely, R.A. Influence of red pepper spice and turmeric on inflammation and oxidative stress biomarkers in overweight females: A metabolomics approach. Plant Foods Hum. Nutr. 2012, 67, 415-421. [CrossRef] [PubMed]

82. Arun, N.; Nalini, N. Efficacy of turmeric on blood sugar and polyol pathway in diabetic albino rats. Plant Foods Hum. Nutr. 2002, 57, 41-52. [CrossRef] [PubMed]

83. Jain, S.K.; Rains, J.; Jones, K. Effect of curcumin on protein glycosylation, lipid peroxidation, and oxygen radical generation in human red blood cells exposed to high glucose levels. Free Radic. Biol. Med. 2006, 41, 92-96. [CrossRef] [PubMed]

84. Muthenna, P.; Suryanarayana, P.; Gunda, S.K.; Petrash, J.M.; Reddy, G.B. Inhibition of aldose reductase by dietary antioxidant curcumin: Mechanism of inhibition, specificity and significance. FEBS Lett. 2009, 583, 3637-3642. [CrossRef] [PubMed]

85. Pfeifer, M.A.; Schumer, M.P.; Gelber, D.A. Aldose reductase inhibitors: The end of an era or the need for different trial designs? Diabetes 1997, 46 (Suppl. 2), S82-S89. [CrossRef]

86. Tomlinson, D.R.; Willars, G.B.; Carrington, A.L. Aldose reductase inhibitors and diabetic complications. Pharmacol. Ther. 1992, 54, 151. [CrossRef]

87. Suryanarayana, P.; Satyanarayana, A.; Balakrishna, N.; Kumar, P.U.; Reddy, G.B. Effect of turmeric and curcumin on oxidative stress and antioxidant enzymes in streptozotocin-induced diabetic rat. Med. Sci. Monit. 2007, 13, BR286-BR292. [PubMed]

88. Pari, L.; Murugan, P. Tetrahydrocurcumin prevents brain lipid peroxidation in streptozotocin-induced diabetic rats. J. Med. Food 2007, 10, 323-329. [CrossRef] [PubMed]

89. Balamurugan, A.N.; Akhov, L.; Selvaraj, G.; Pugazhenthi, S. Induction of antioxidant enzymes by curcumin and its analogues in human islets: Implications in transplantation. Pancreas 2009, 38, 454-460. [CrossRef] [PubMed]

90. Balogun, E.; Hoque, M.; Gong, P.; Killeen, E.; Green, C.J.; Foresti, R.; Alam, J.; Motterlini, R. Curcumin activates the haem oxygenase-1 gene via regulation of $\mathrm{Nrf} 2$ and the antioxidant-responsive element. Biochem. J. 2003, 371, 887-895. [CrossRef] [PubMed]

91. Meghana, K.; Sanjeev, G.; Ramesh, B. Curcumin prevents streptozotocin-induced islet damage by scavenging free radicals: A prophylactic and protective role. Eur. J. Pharmacol. 2007, 577, 183-191. [CrossRef] [PubMed]

92. Balasubramanyam, M.; Koteswari, A.A.; Kumar, R.S.; Monickaraj, S.F.; Maheswari, J.U.; Mohan, V. Curcumin-induced inhibition of cellular reactive oxygen species generation: Novel therapeutic implications. J. Biosci. 2003, 28, 715-721. [CrossRef] [PubMed]

93. Seo, K.I.; Choi, M.S.; Jung, U.J.; Kim, H.J.; Yeo, J.; Jeon, S.M.; Lee, M.K. Effect of curcumin supplementation on blood glucose, plasma insulin, and glucose homeostasis related enzyme activities in diabetic $\mathrm{db} / \mathrm{db}$ mice. Mol. Nutr. Food Res. 2008, 52, 995-1004. [CrossRef] [PubMed]

94. Virag, L. Structure and function of poly(ADP-ribose) polymerase-1: Role in oxidative stress-related pathologies. Curr. Vasc. Pharmacol. 2005, 3, 209-214. [CrossRef] [PubMed]

95. Hegedus, C.; Virag, L. Inputs and outputs of poly(ADP-ribosyl)ation: Relevance to oxidative stress. Redox Biol. 2014, 2, 978-982. [CrossRef] [PubMed]

96. Tang, W.H.; Martin, K.A.; Hwa, J. Aldose reductase, oxidative stress, and diabetic mellitus. Front. Pharmacol. 2012, 3, 87. [CrossRef] [PubMed]

97. Hu, X.; Li, S.; Yang, G.; Liu, H.; Boden, G.; Li, L. Efficacy and safety of aldose reductase inhibitor for the treatment of diabetic cardiovascular autonomic neuropathy: Systematic review and meta-analysis. PLoS ONE 2014, 9, e87096. [CrossRef] [PubMed]

98. Shao, W.; Yu, Z.; Chiang, Y.; Yang, Y.; Chai, T.; Foltz, W.; Lu, H.; Fantus, I.G.; Jin, T. Curcumin prevents high fat diet induced insulin resistance and obesity via attenuating lipogenesis in liver and inflammatory pathway in adipocytes. PLoS ONE 2012, 7, e28784. [CrossRef] [PubMed]

99. Beal, M.F. Therapeutic approaches to mitochondrial dysfunction in parkinson's disease. Parkinsonism Relat. Disord. 2009, 15 (Suppl. 3), S189-S194. [CrossRef]

100. Mohammadi, A.; Sahebkar, A.; Iranshahi, M.; Amini, M.; Khojasteh, R.; Ghayour-Mobarhan, M.; Ferns, G.A. Effects of supplementation with curcuminoids on dyslipidemia in obese patients: A randomized crossover trial. Phytother. Res. 2013, 27, 374-379. [CrossRef] [PubMed] 
101. Wongcharoen, W.; Jai-Aue, S.; Phrommintikul, A.; Nawarawong, W.; Woragidpoonpol, S.; Tepsuwan, T.; Sukonthasarn, A.; Apaijai, N.; Chattipakorn, N. Effects of curcuminoids on frequency of acute myocardial infarction after coronary artery bypass grafting. Am. J. Cardiol. 2012, 110, 40-44. [CrossRef] [PubMed]

102. Panahi, Y.; Sahebkar, A.; Parvin, S.; Saadat, A. A randomized controlled trial on the anti-inflammatory effects of curcumin in patients with chronic sulphur mustard-induced cutaneous complications. Ann. Clin. Biochem. 2012, 49, 580-588. [CrossRef] [PubMed]

103. Chainani-Wu, N.; Madden, E.; Lozada-Nur, F.; Silverman, S., Jr. High-dose curcuminoids are efficacious in the reduction in symptoms and signs of oral lichen planus. J. Am. Acad. Dermatol. 2012, 66, 752-760. [CrossRef] [PubMed]

104. Belcaro, G.; Cesarone, M.R.; Dugall, M.; Pellegrini, L.; Ledda, A.; Grossi, M.G.; Togni, S.; Appendino, G. Product-evaluation registry of meriva(r), a curcumin-phosphatidylcholine complex, for the complementary management of osteoarthritis. Panminerva Med. 2010, 52, 55-62. [PubMed]

105. Panahi, Y.; Saadat, A.; Beiraghdar, F.; Hosseini Nouzari, S.M.; Jalalian, H.R.; Sahebkar, A. Antioxidant effects of bioavailability-enhanced curcuminoids in patients with solid tumors: A randomized double-blind placebo-controlled trial. J. Funct. Foods 2014, 6, 615-622. [CrossRef]

106. Rahimnia, A.R.; Panahi, Y.; Alishiri, G.; Sharafi, M.; Sahebkar, A. Impact of supplementation with curcuminoids on systemic inflammation in patients with knee osteoarthritis: Findings from a randomized double-blind placebo-controlled trial. Drug Res. 2015, 65, 521-525. [CrossRef] [PubMed]

107. Panahi, Y.; Hosseini, M.S.; Khalili, N.; Naimi, E.; Majeed, M.; Sahebkar, A. Antioxidant and anti-inflammatory effects of curcuminoid-piperine combination in subjects with metabolic syndrome: A randomized controlled trial and an updated meta-analysis. Clin. Nutr. 2015, 34, 1101-1108. [CrossRef] [PubMed]

108. Usharani, P.; Mateen, A.A.; Naidu, M.U.; Raju, Y.S.; Chandra, N. Effect of NCB-02, atorvastatin and placebo on endothelial function, oxidative stress and inflammatory markers in patients with type 2 diabetes mellitus: A randomized, parallel-group, placebo-controlled, 8-week study. Drugs $R$ D 2008, 9, 243-250. [CrossRef] [PubMed]

109. Na, L.X.; Yan, B.L.; Jiang, S.; Cui, H.L.; Li, Y.; Sun, C.H. Curcuminoids target decreasing serum adipocyte-fatty acid binding protein levels in their glucose-lowering effect in patients with type 2 diabetes. Biomed. Environ. Sci. 2014, 27, 902-906. [PubMed]

110. Yu, J.J.; Pei, L.B.; Zhang, Y.; Wen, Z.Y.; Yang, J.L. Chronic supplementation of curcumin enhances the efficacy of antidepressants in major depressive disorder: A randomized, double-blind, placebo-controlled pilot study. J. Clin. Psychopharmacol. 2015, 35, 406-410. [CrossRef] [PubMed]

111. Ganjali, S.; Sahebkar, A.; Mahdipour, E.; Jamialahmadi, K.; Torabi, S.; Akhlaghi, S.; Ferns, G.; Parizadeh, S.M.R.; Ghayour-Mobarhan, M. Investigation of the effects of curcumin on serum cytokines in obese individuals: A randomized controlled trial. Sci. World J. 2014, 11, 6. [CrossRef] [PubMed]

112. Panahi, Y.; Hosseini, M.S.; Khalili, N.; Naimi, E.; Simental-Mendia, L.E.; Majeed, M.; Sahebkar, A. Effects of curcumin on serum cytokine concentrations in subjects with metabolic syndrome: A post-hoc analysis of a randomized controlled trial. Biomed. Pharmacother. 2016, 82, 578-582. [CrossRef] [PubMed]

113. Khajehdehi, P.; Pakfetrat, M.; Javidnia, K.; Azad, F.; Malekmakan, L.; Nasab, M.H.; Dehghanzadeh, G. Oral supplementation of turmeric attenuates proteinuria, transforming growth factor-beta and interleukin-8 levels in patients with overt type 2 diabetic nephropathy: A randomized, double-blind and placebo-controlled study. Scand. J. Urol. Nephrol. 2011, 45, 365-370. [CrossRef] [PubMed]

114. Sahebkar, A.; Cicero, A.F.G.; Simental-Mendia, L.E.; Aggarwal, B.B.; Gupta, S.C. Curcumin downregulates human tumor necrosis factor-alpha levels: A systematic review and meta-analysis ofrandomized controlled trials. Pharmacol. Res. 2016, 107, 234-242. [CrossRef] [PubMed]

115. Panahi, Y.; Ghanei, M.; Bashiri, S.; Hajihashemi, A.; Sahebkar, A. Short-term curcuminoid supplementation for chronic pulmonary complications due to sulfur mustard intoxication: Positive results of a randomized double-blind placebo-controlled trial. Drug Res. 2015, 65, 567-573. [CrossRef] [PubMed]

116. Gupta, S.C.; Tyagi, A.K.; Deshmukh-Taskar, P.; Hinojosa, M.; Prasad, S.; Aggarwal, B.B. Downregulation of tumor necrosis factor and other proinflammatory biomarkers by polyphenols. Arch. Biochem. Biophys. 2014, 559, 91-99. [CrossRef] [PubMed]

117. Derosa, G.; Maffioli, P.; Simental-Mendia, L.E.; Bo, S.; Sahebkar, A. Effect of curcumin on circulating interleukin-6 concentrations: A systematic review and meta-analysis of randomized controlled trials. Pharmacol. Res. 2016, 111, 394-404. [CrossRef] [PubMed] 
118. Pearson, G.; Robinson, F.; Beers Gibson, T.; Xu, B.E.; Karandikar, M.; Berman, K.; Cobb, M.H. Mitogenactivated protein (MAP) kinase pathways: Regulation and physiological functions. Endocr. Rev. 2001, 22, 153-183. [CrossRef] [PubMed]

119. Kim, E.K.; Choi, E.J. Pathological roles of MAPK signaling pathways in human diseases. Biochim. Biophys. Acta 2010, 1802, 396-405. [CrossRef] [PubMed]

120. Errede, B.; Cade, R.M.; Yashar, B.M.; Kamada, Y.; Levin, D.E.; Irie, K.; Matsumoto, K. Dynamics and organization of map kinase signal pathways. Mol. Reprod. Dev. 1995, 42, 477-485. [CrossRef] [PubMed]

121. Herlaar, E.; Brown, Z. P38 MAPK signalling cascades in inflammatory disease. Mol. Med. Today 1999, 5, 439-447. [CrossRef]

122. Kaminska, B. MAPK signalling pathways as molecular targets for anti-inflammatory therapy-From molecular mechanisms to therapeutic benefits. Biochim. Biophys. Acta 2005, 1754, 253-262. [CrossRef] [PubMed]

123. Ogawa, H.; Binion, D.G.; Heidemann, J.; Theriot, M.; Fisher, P.J.; Johnson, N.A.; Otterson, M.F.; Rafiee, P. Mechanisms of madcam-1 gene expression in human intestinal microvascular endothelial cells. Am. J. Physiol. Cell Physiol. 2005, 288, C272-C281. [CrossRef] [PubMed]

124. Rafiee, P.; Johnson, C.P.; Li, M.S.; Ogawa, H.; Heidemann, J.; Fisher, P.J.; Lamirand, T.H.; Otterson, M.F.; Wilson, K.T.; Binion, D.G. Cyclosporine a enhances leukocyte binding by human intestinal microvascular endothelial cells through inhibition of p38 MAPK and inos. Paradoxical proinflammatory effect on the microvascular endothelium. J. Biol. Chem. 2002, 277, 35605-35615. [CrossRef] [PubMed]

125. Gonzales, A.M.; Orlando, R.A. Curcumin and resveratrol inhibit nuclear factor-kappaB-mediated cytokine expression in adipocytes. Nutr. Metab. 2008, 5, 17. [CrossRef] [PubMed]

126. Wang, S.L.; Li, Y.; Wen, Y.; Chen, Y.F.; Na, L.X.; Li, S.T.; Sun, C.H. Curcumin, a potential inhibitor of up-regulation of TNF-alpha and IL-6 induced by palmitate in 3T3-L1 adipocytes through Nf-kappaB and JNK pathway. Biomed. Environ. Sci. 2009, 22, 32-39. [CrossRef]

127. Woo, H.-M.; Kang, J.-H.; Kawada, T.; Yoo, H.; Sung, M.-K.; Yu, R. Active spice-derived components can inhibit inflammatory responses of adipose tissue in obesity by suppressing inflammatory actions of macrophages and release of monocyte chemoattractant protein-1 from adipocytes. Life Sci. 2007, 80, 926-931. [CrossRef] [PubMed]

128. Geng, S.; Wang, S.; Zhu, W.; Xie, C.; Li, X.; Wu, J.; Zhu, J.; Jiang, Y.; Yang, X.; Li, Y.; et al. Curcumin suppresses JNK pathway to attenuate BPA-induced insulin resistance in LO2 cells. Biomed. Pharmacother. 2018, 97, 1538-1543. [CrossRef] [PubMed]

129. Sadeghi, A.; Rostamirad, A.; Seyyedebrahimi, S.; Meshkani, R. Curcumin ameliorates palmitate-induced inflammation in skeletal muscle cells by regulating JNK/NF- $\mathrm{KB}$ pathway and ROS production. Inflammopharmacology 2018, 26, 1265-1272. [CrossRef] [PubMed]

130. Geng, S.; Wang, S.; Zhu, W.; Xie, C.; Li, X.; Wu, J.; Zhu, J.; Jiang, Y.; Yang, X.; Li, Y.; et al. Curcumin attenuates bpa-induced insulin resistance in HepG2 cells through suppression of JNK/p38 pathways. Toxicol. Lett. 2017, 272, 75-83. [CrossRef] [PubMed]

131. Masamune, A.; Suzuki, N.; Kikuta, K.; Satoh, M.; Satoh, K.; Shimosegawa, T. Curcumin blocks activation of pancreatic stellate cells. J. Cell. Biochem. 2006, 97, 1080-1093. [CrossRef] [PubMed]

132. Yun, J.M.; Jialal, I.; Devaraj, S. Epigenetic regulation of high glucose-induced proinflammatory cytokine production in monocytes by curcumin. J. Nutr. Biochem. 2011, 22, 450-458. [CrossRef] [PubMed]

133. Pham, T.X.; Lee, J. Dietary regulation of histone acetylases and deacetylases for the prevention of metabolic diseases. Nutrients 2012, 4, 1868-1886. [CrossRef] [PubMed]

134. Rahmani, S.; Asgary, S.; Askari, G.; Keshvari, M.; Hatamipour, M.; Feizi, A.; Sahebkar, A. Treatment of non-alcoholic fatty liver disease with curcumin: A randomized placebo-controlled trial. Phytother. Res. 2016, 30, 1540-1548. [CrossRef] [PubMed]

135. Na, L.X.; Li, Y.; Pan, H.Z.; Zhou, X.L.; Sun, D.J.; Meng, M.; Li, X.X.; Sun, C.H. Curcuminoids exert glucose-lowering effect in type 2 diabetes by decreasing serum free fatty acids: A double-blind, placebo-controlled trial. Mol. Nutr. Food Res. 2013, 57, 1569-1577. [CrossRef] [PubMed]

136. Chuengsamarn, S.; Rattanamongkolgul, S.; Luechapudiporn, R.; Phisalaphong, C.; Jirawatnotai, S. Curcumin extract for prevention of type 2 diabetes. Diabetes Care 2012, 35, 2121-2127. [CrossRef] [PubMed]

137. Liu, M.; Liu, F. Regulation of adiponectin multimerization, signaling and function. Best Pract. Res. Clin. Endocrinol. Metab. 2014, 28, 25-31. [CrossRef] [PubMed] 
138. Salahshooh, M.; Parizadeh, S.; Pasdar, A.; Saberi Karimian, M.; Safarian, H.; Javandoost, A.; Ferns, G.; Ghayour-Mobarhan, M.; Sahebkar, A. The effect of curcumin (Curcuma longa L.) on circulating levels of adiponectin in patients with metabolic syndrome. Comp. Clin. Pathol. 2017, 26, 17-23. [CrossRef]

139. Chuengsamarn, S.; Rattanamongkolgul, S.; Phonrat, B.; Tungtrongchitr, R.; Jirawatnotai, S. Reduction of atherogenic risk in patients with type 2 diabetes by curcuminoid extract: A randomized controlled trial. J. Nutr. Biochem. 2014, 25, 144-150. [CrossRef] [PubMed]

140. Tang, M.; Larson-Meyer, D.E.; Liebman, M. Effect of cinnamon and turmeric on urinary oxalate excretion, plasma lipids, and plasma glucose in healthy subjects. Am. J. Clin. Nutr. 2008, 87, 1262-1267. [CrossRef] [PubMed]

141. Wickenberg, J.; Ingemansson, S.L.; Hlebowicz, J. Effects of Curcuma longa (turmeric) on postprandial plasma glucose and insulin in healthy subjects. Nutr. J. 2010, 9, 43. [CrossRef] [PubMed]

142. Franco-Robles, E.; Campos-Cervantes, A.; Murillo-Ortiz, B.O.; Segovia, J.; Lopez-Briones, S.; Vergara, P.; Perez-Vazquez, V.; Solis-Ortiz, M.S.; Ramirez-Emiliano, J. Effects of curcumin on brain-derived neurotrophic factor levels and oxidative damage in obesity and diabetes. Appl. Physiol. Nutr. Metab. 2014, 39, 211-218. [CrossRef] [PubMed]

143. Yang, Y.S.; Su, Y.F.; Yang, H.W.; Lee, Y.H.; Chou, J.I.; Ueng, K.C. Lipid-lowering effects of curcumin in patients with metabolic syndrome: A randomized, double-blind, placebo-controlled trial. Phytother. Res. 2014, 28, 1770-1777. [CrossRef] [PubMed]

144. Santos-Parker, J.R.; Strahler, T.R.; Bassett, C.J.; Bispham, N.Z.; Chonchol, M.B.; Seals, D.R. Curcumin supplementation improves vascular endothelial function in healthy middle-aged and older adults by increasing nitric oxide bioavailability and reducing oxidative stress. Aging 2017, 9, 187-208. [CrossRef] [PubMed]

145. Alwi, I.; Santoso, T.; Suyono, S.; Sutrisna, B.; Suyatna, F.D.; Kresno, S.B.; Ernie, S. The effect of curcumin on lipid level in patients with acute coronary syndrome. Acta Med. Indones. 2008, 40, 201-210. [PubMed]

146. Panahi, Y.; Kianpour, P.; Mohtashami, R.; Jafari, R.; Simental-Mendia, L.E.; Sahebkar, A. Curcumin lowers serum lipids and uric acid in subjects with nonalcoholic fatty liver disease: A randomized controlled trial. J. Cardiovasc. Pharmacol. 2016, 68, 223-229. [CrossRef] [PubMed]

147. Na, L.X.; Zhang, Y.L.; Li, Y.; Liu, L.Y.; Li, R.; Kong, T.; Sun, C.H. Curcumin improves insulin resistance in skeletal muscle of rats. Nutr. Metab. Cardiovasc. Dis. 2011, 21, 526-533. [CrossRef] [PubMed]

148. Hardie, D.G. AMPK: A key regulator of energy balance in the single cell and the whole organism. Int. J. Obes. 2008, 32 (Suppl. 4), S7-S12. [CrossRef]

149. Hardie, D.G. AMP-activated protein kinase: An energy sensor that regulates all aspects of cell function. Genes Dev. 2011, 25, 1895-1908. [CrossRef] [PubMed]

150. Deng, Y.T.; Chang, T.W.; Lee, M.S.; Lin, J.K. Suppression of free fatty acid-induced insulin resistance by phytopolyphenols in C2C12 mouse skeletal muscle cells. J. Agric. Food Chem. 2012, 60, 1059-1066. [CrossRef] [PubMed]

151. Kim, J.H.; Park, J.M.; Kim, E.K.; Lee, J.O.; Lee, S.K.; Jung, J.H.; You, G.Y.; Park, S.H.; Suh, P.G.; Kim, H.S. Curcumin stimulates glucose uptake through AMPK-p38 MAPK pathways in 16 myotube cells. J. Cell. Physiol. 2010, 223, 771-778. [CrossRef] [PubMed]

152. Li, J.M.; Li, Y.C.; Kong, L.D.; Hu, Q.H. Curcumin inhibits hepatic protein-tyrosine phosphatase $1 \mathrm{~B}$ and prevents hypertriglyceridemia and hepatic steatosis in fructose-fed rats. Hepatology 2010, 51, 1555-1566. [CrossRef] [PubMed]

153. Hao, F.; Kang, J.; Cao, Y.; Fan, S.; Yang, H.; An, Y.; Pan, Y.; Tie, L.; Li, X. Curcumin attenuates palmitateinduced apoptosis in min6 pancreatic $\beta$-cells through $\mathrm{PI}_{3} \mathrm{~K} / \mathrm{Akt} / \mathrm{FO}_{\mathrm{x}} \mathrm{O}_{1}$ and mitochondrial survival pathways. Apoptosis 2015, 20, 1420-1432. [CrossRef] [PubMed]

154. Best, L.; Elliott, A.C.; Brown, P.D. Curcumin induces electrical activity in rat pancreatic beta-cells by activating the volume-regulated anion channel. Biochem. Pharmacol. 2007, 73, 1768-1775. [CrossRef] [PubMed]

155. Rouse, M.; Younes, A.; Egan, J.M. Resveratrol and curcumin enhance pancreatic beta-cell function by inhibiting phosphodiesterase activity. J. Endocrinol. 2014, 223, 107-117. [CrossRef] [PubMed]

156. Weisberg, S.P.; Leibel, R.; Tortoriello, D.V. Dietary curcumin significantly improves obesity-associated inflammation and diabetes in mouse models of diabesity. Endocrinology 2008, 149, 3549-3558. [CrossRef] [PubMed]

157. Qiao, L.; Shao, J. SIRT1 regulates adiponectin gene expression through foxo1-C/enhancer-binding protein alpha transcriptional complex. J. Biol. Chem. 2006, 281, 39915-39924. [CrossRef] [PubMed] 
158. Rodgers, J.T.; Lerin, C.; Haas, W.; Gygi, S.P.; Spiegelman, B.M.; Puigserver, P. Nutrient control of glucose homeostasis through a complex of PGC-1alpha and SIRT1. Nature 2005, 434, 113-118. [CrossRef] [PubMed]

159. Picard, F.; Auwerx, J. Ppar(gamma) and glucose homeostasis. Annu. Rev. Nutr. 2002, 22, 167-197. [CrossRef] [PubMed]

160. Baum, L.; Cheung, S.K.; Mok, V.C.; Lam, L.C.; Leung, V.P.; Hui, E.; Ng, C.C.; Chow, M.; Ho, P.C.; Lam, S.; et al. Curcumin effects on blood lipid profile in a 6-month human study. Pharmacol. Res. 2007, 56, 509-514. [CrossRef] [PubMed]

161. Ferguson, J.J.A.; Stojanovski, E.; MacDonald-Wicks, L.; Garg, M.L. Curcumin potentiates cholesterol-lowering effects of phytosterols in hypercholesterolaemic individuals. A randomised controlled trial. Metabolism 2018, 82, 22-35. [CrossRef] [PubMed]

162. Sahebkar, A. A systematic review and meta-analysis of randomized controlled trials investigating the effects of curcumin on blood lipid levels. Clin. Nutr. 2014, 33, 406-414. [CrossRef] [PubMed]

163. Panahi, Y.; Khalili, N.; Hosseini, M.S.; Abbasinazari, M.; Sahebkar, A. Lipid-modifying effects of adjunctive therapy with curcuminoids-piperine combination in patients with metabolic syndrome: Results of a randomized controlled trial. Complement. Ther. Med. 2014, 22, 851-857. [CrossRef] [PubMed]

164. Cicero, A.F.G.; Colletti, A.; Bajraktari, G.; Descamps, O.; Djuric, D.M.; Ezhov, M.; Fras, Z.; Katsiki, N.; Langlois, M.; Latkovskis, G.; et al. Lipid lowering nutraceuticals in clinical practice: Position paper from an international lipid expert panel. Arch. Med. Sci. 2017, 13, 965-1005. [CrossRef] [PubMed]

165. Saenz, J.; Alba, G.; Reyes-Quiroz, M.E.; Geniz, I.; Jimenez, J.; Sobrino, F.; Santa-Maria, C. Curcumin enhances LXRalpha in an AMP-activated protein kinase-dependent manner in human macrophages. J. Nutr. Biochem. 2018, 54, 48-56. [CrossRef] [PubMed]

166. Peschel, D.; Koerting, R.; Nass, N. Curcumin induces changes in expression of genes involved in cholesterol homeostasis. J. Nutr. Biochem. 2007, 18, 113-119. [CrossRef] [PubMed]

167. Ding, L.; Li, J.; Song, B.; Xiao, X.; Zhang, B.; Qi, M.; Huang, W.; Yang, L.; Wang, Z. Curcumin rescues high fat diet-induced obesity and insulin sensitivity in mice through regulating srebp pathway. Toxicol. Appl. Pharmacol. 2016, 304, 99-109. [CrossRef] [PubMed]

168. Um, M.Y.; Hwang, K.H.; Ahn, J.; Ha, T.Y. Curcumin attenuates diet-induced hepatic steatosis by activating AMP-activated protein kinase. Basic Clin. Pharmacol. Toxicol. 2013, 113, 152-157. [CrossRef] [PubMed]

169. Ejaz, A.; Wu, D.; Kwan, P.; Meydani, M. Curcumin inhibits adipogenesis in 3T3-L1 adipocytes and angiogenesis and obesity in C57/BL mice. J. Nutr. 2009, 139, 919-925. [CrossRef] [PubMed]

170. El-Moselhy, M.A.; Taye, A.; Sharkawi, S.S.; El-Sisi, S.F.; Ahmed, A.F. The antihyperglycemic effect of curcumin in high fat diet fed rats. Role of TNF-alpha and free fatty acids. Food Chem. Toxicol. 2011, 49, 1129-1140. [CrossRef] [PubMed]

171. Babu, P.S.; Srinivasan, K. Hypolipidemic action of curcumin, the active principle of turmeric (Curcuma longa) in streptozotocin induced diabetic rats. Mol. Cell. Biochem. 1997, 166, 169-175. [CrossRef] [PubMed]

172. Jang, E.M.; Choi, M.S.; Jung, U.J.; Kim, M.J.; Kim, H.J.; Jeon, S.M.; Shin, S.K.; Seong, C.N.; Lee, M.K. Beneficial effects of curcumin on hyperlipidemia and insulin resistance in high-fat-fed hamsters. Metabolism 2008, 57, 1576-1583. [CrossRef] [PubMed]

173. Maithilikarpagaselvi, N.; Sridhar, M.G.; Swaminathan, R.P.; Sripradha, R.; Badhe, B. Curcumin inhibits hyperlipidemia and hepatic fat accumulation in high-fructose-fed male wistar rats. Pharm. Biol. 2016, 54, 2857-2863. [CrossRef] [PubMed]

174. Oner-Iyidogan, Y.; Kocak, H.; Seyidhanoglu, M.; Gurdol, F.; Gulcubuk, A.; Yildirim, F.; Cevik, A.; Uysal, M. Curcumin prevents liver fat accumulation and serum fetuin-a increase in rats fed a high-fat diet. J. Physiol. Biochem. 2013, 69, 677-686. [CrossRef] [PubMed]

175. Shin, S.K.; Ha, T.Y.; McGregor, R.A.; Choi, M.S. Long-term curcumin administration protects against atherosclerosis via hepatic regulation of lipoprotein cholesterol metabolism. Mol. Nutr. Food Res. 2011, 55, 1829-1840. [CrossRef] [PubMed]

176. Prakash, U.N.; Srinivasan, K. Fat digestion and absorption in spice-pretreated rats. J. Sci. Food Agric. 2012, 92, 503-510. [CrossRef] [PubMed]

177. Kim, M.; Kim, Y. Hypocholesterolemic effects of curcumin via up-regulation of cholesterol 7a-hydroxylase in rats fed a high fat diet. Nutr. Res. Pract. 2010, 4, 191-195. [CrossRef] [PubMed]

178. Yap, F.; Craddock, L.; Yang, J. Mechanism of AMPK suppression of LXR-dependent Srebp-1c transcription. Int. J. Biol. Sci. 2011, 7, 645-650. [CrossRef] [PubMed] 
179. Denechaud, P.D.; Dentin, R.; Girard, J.; Postic, C. Role of chrebp in hepatic steatosis and insulin resistance. FEBS Lett. 2008, 582, 68-73. [CrossRef] [PubMed]

180. Dong, S.Z.; Zhao, S.P.; Wu, Z.H.; Yang, J.; Xie, X.Z.; Yu, B.L.; Nie, S. Curcumin promotes cholesterol efflux from adipocytes related to ppargamma-lxralpha-abca1 passway. Mol. Cell. Biochem. 2011, 358, 281-285. [CrossRef] [PubMed]

181. Kumar, P.; Malhotra, P.; Ma, K.; Singla, A.; Hedroug, O.; Saksena, S.; Dudeja, P.K.; Gill, R.K.; Alrefai, W.A. Srebp2 mediates the modulation of intestinal NPC1L1 expression by curcumin. Am. J. Physiol. Gastrointest. Liver Physiol. 2011, 301, G148-G155. [CrossRef] [PubMed]

182. Feng, D.; Ohlsson, L.; Duan, R.D. Curcumin inhibits cholesterol uptake in Caco-2 cells by down-regulation of NPC1L1 expression. Lipids Health Dis. 2010, 9, 40. [CrossRef] [PubMed]

183. Stefan, N.; Hennige, A.M.; Staiger, H.; Machann, J.; Schick, F.; Krober, S.M.; Machicao, F.; Fritsche, A.; Haring, H.U. Alpha2-heremans-schmid glycoprotein/fetuin-A is associated with insulin resistance and fat accumulation in the liver in humans. Diabetes Care 2006, 29, 853-857. [CrossRef] [PubMed]

184. Mori, K.; Emoto, M.; Araki, T.; Yokoyama, H.; Lee, E.; Teramura, M.; Koyama, H.; Shoji, T.; Inaba, M.; Nishizawa, Y. Effects of pioglitazone on serum fetuin-a levels in patients with type 2 diabetes mellitus. Metabolism 2008, 57, 1248-1252. [CrossRef] [PubMed]

185. Hariri, M.; Haghighatdoost, F. Effect of curcumin on anthropometric measures: A systematic review on randomized clinical trials. J. Am. Coll. Nutr. 2018, 37, 215-222. [CrossRef] [PubMed]

186. Esmaily, H.; Sahebkar, A.; Iranshahi, M.; Ganjali, S.; Mohammadi, A.; Ferns, G.; Ghayour-Mobarhan, M. An investigation of the effects of curcumin on anxiety and depression in obese individuals: A randomized controlled trial. Chin. J. Integr. Med. 2015, 21, 332-338. [CrossRef] [PubMed]

187. Ikonomov, O.C.; Sbrissa, D.; Mlak, K.; Shisheva, A. Requirement for PIKfyve enzymatic activity in acute and long-term insulin cellular effects. Endocrinology 2002, 143, 4742-4754. [CrossRef] [PubMed]

188. Green, A.; Krause, J.; Rumberger, J.M. Curcumin is a direct inhibitor of glucose transport in adipocytes. Phytomedicine 2014, 21, 118-122. [CrossRef] [PubMed]

189. Zhang, D.; Zhang, Y.; Ye, M.; Ding, Y.; Tang, Z.; Li, M.; Zhou, Y.; Wang, C. Interference with Akt signaling pathway contributes curcumin-induced adipocyte insulin resistance. Mol. Cell. Endocrinol. 2016, 429, 1-9. [CrossRef] [PubMed]

190. Mar-Heyming, R.; Miyazaki, M.; Weissglas-Volkov, D.; Kolaitis, N.A.; Sadaat, N.; Plaisier, C.; Pajukanta, P.; Cantor, R.M.; de Bruin, T.W.; Ntambi, J.M.; et al. Association of stearoyl-coa desaturase 1 activity with familial combined hyperlipidemia. Arterioscler. Thromb. Vasc. Biol. 2008, 28, 1193-1199. [CrossRef] [PubMed]

191. Sampath, H.; Ntambi, J.M. The role of stearoyl-coa desaturase in obesity, insulin resistance, and inflammation. Ann. N. Y. Acad. Sci. 2011, 1243, 47-53. [CrossRef] [PubMed]

192. Wang, S.; Wang, X.; Ye, Z.; Xu, C.; Zhang, M.; Ruan, B.; Wei, M.; Jiang, Y.; Zhang, Y.; Wang, L.; et al. Curcumin promotes browning of white adipose tissue in a norepinephrine-dependent way. Biochem. Biophys. Res. Commun. 2015, 466, 247-253. [CrossRef] [PubMed]

193. Lone, J.; Choi, J.H.; Kim, S.W.; Yun, J.W. Curcumin induces brown fat-like phenotype in 3T3-L1 and primary white adipocytes. J. Nutr. Biochem. 2016, 27, 193-202. [CrossRef] [PubMed]

194. Kim, S.W.; Choi, J.H.; Mukherjee, R.; Hwang, K.C.; Yun, J.W. Proteomic identification of fat-browning markers in cultured white adipocytes treated with curcumin. Mol. Cell. Biochem. 2016, 415, 51-66. [CrossRef] [PubMed]

195. Cannon, B.; Nedergaard, J. Brown adipose tissue: Function and physiological significance. Physiol. Rev. 2004, 84, 277-359. [CrossRef] [PubMed]

196. Harms, M.; Seale, P. Brown and beige fat: Development, function and therapeutic potential. Nat. Med. 2013, 19, 1252-1263. [CrossRef] [PubMed]

197. Vitali, A.; Murano, I.; Zingaretti, M.C.; Frontini, A.; Ricquier, D.; Cinti, S. The adipose organ of obesity-prone C57BL/6J mice is composed of mixed white and brown adipocytes. J. Lipid Res. 2012, 53, 619-629. [CrossRef] [PubMed]

198. Fenzl, A.; Kiefer, F.W. Brown adipose tissue and thermogenesis. Horm. Mol. Biol. Clin. Investig. 2014, 19, 25-37. [CrossRef] [PubMed]

199. Lee, Y.H.; Mottillo, E.P.; Granneman, J.G. Adipose tissue plasticity from wat to bat and in between. Biochim. Biophys. Acta 2014, 1842, 358-369. [CrossRef] [PubMed]

200. Hu, J.; Christian, M. Hormonal factors in the control of the browning of white adipose tissue. Horm. Mol. Biol. Clin. Investig. 2017, 31. [CrossRef] [PubMed] 
201. Cao, Y.; Wang, H.; Zeng, W. Whole-tissue 3D imaging reveals intra-adipose sympathetic plasticity regulated by NGF-TrkA signal in cold-induced beiging. Protein Cell 2018, 9, 527-539. [CrossRef] [PubMed]

202. Sidossis, L.S.; Porter, C.; Saraf, M.K.; Borsheim, E.; Radhakrishnan, R.S.; Chao, T.; Ali, A.; Chondronikola, M.; Mlcak, R.; Finnerty, C.C.; et al. Browning of subcutaneous white adipose tissue in humans after severe adrenergic stress. Cell Metab. 2015, 22, 219-227. [CrossRef] [PubMed]

203. Ahn, J.; Lee, H.; Kim, S.; Ha, T. Curcumin-induced suppression of adipogenic differentiation is accompanied by activation of Wnt/beta-catenin signaling. Am. J. Physiol. Cell Physiol. 2010, 298, C1510-C1516. [CrossRef] [PubMed]

204. Logan, A.C.; Jacka, F.N.; Prescott, S.L. Immune-microbiota interactions: Dysbiosis as a global health issue. Curr. Allergy Asthma Rep. 2016, 16, 13. [CrossRef] [PubMed]

205. Monda, V.; Villano, I.; Messina, A.; Valenzano, A.; Esposito, T.; Moscatelli, F.; Viggiano, A.; Cibelli, G.; Chieffi, S.; Monda, M.; et al. Exercise modifies the gut microbiota with positive health effects. Oxid. Med. Cell. Longev. 2017, 2017, 3831972. [CrossRef] [PubMed]

206. Poroyko, V.A.; Carreras, A.; Khalyfa, A.; Khalyfa, A.A.; Leone, V.; Peris, E.; Almendros, I.; Gileles-Hillel, A.; Qiao, Z.; Hubert, N.; et al. Chronic sleep disruption alters gut microbiota, induces systemic and adipose tissue inflammation and insulin resistance in mice. Sci. Rep. 2016, 6, 35405. [CrossRef] [PubMed]

207. Brahe, L.; Astrup, A.; Larsen, L. Can we prevent obesity-related metabolic diseases by dietary modulation of the gut microbiota? Adv. Nutr. 2016, 7, 90-101. [CrossRef] [PubMed]

208. Karlsson, F.; Tremaroli, V.; Nielsen, J.; Backhed, F. Assessing the human gut microbiota in metabolic diseases. Diabetes 2013, 62, 3341-3349. [CrossRef] [PubMed]

209. Lau, K.; Srivatsav, V.; Rizwan, A.; Nashed, A.; Liu, R.; Shen, R.; Akhtar, M. Bridging the gap between gut microbial dysbiosis and cardiovascular diseases. Nutrients 2017, 9, 859. [CrossRef] [PubMed]

210. Mulak, A.; Bonaz, B. Brain-gut-microbiota axis in parkinson's disease. World J Gastroenterol. 2015, 21, 10609-10620. [CrossRef] [PubMed]

211. Wang, Y.; Kasper, L.H. The role of microbiome in central nervous system disorders. Brain Behav. Immun. 2014, 38, 1-12. [CrossRef] [PubMed]

212. Jiang, C.; Li, G.; Huang, P.; Liu, Z.; Zhao, B. The gut microbiota and alzheimer's disease. J. Alzheimer's Dis. 2017, 58, 1-15. [CrossRef] [PubMed]

213. McFadden, R.M.; Larmonier, C.B.; Shehab, K.W.; Midura-Kiela, M.; Ramalingam, R.; Harrison, C.A.; Besselsen, D.G.; Chase, J.H.; Caporaso, J.G.; Jobin, C.; et al. The role of curcumin in modulating colonic microbiota during colitis and colon cancer prevention. Inflamm. Bowel Dis. 2015, 21, 2483-2494. [CrossRef] [PubMed]

214. Bereswill, S.; Munoz, M.; Fischer, A.; Plickert, R.; Haag, L.M.; Otto, B.; Kuhl, A.A.; Loddenkemper, C.; Gobel, U.B.; Heimesaat, M.M. Anti-inflammatory effects of resveratrol, curcumin and simvastatin in acute small intestinal inflammation. PLoS ONE 2010, 5, e15099. [CrossRef] [PubMed]

215. Kim, J.E.; Lillehoj, H.S.; Hong, Y.H.; Kim, G.B.; Lee, S.H.; Lillehoj, E.P.; Bravo, D.M. Dietary capsicum and Curcuma longa oleoresins increase intestinal microbiome and necrotic enteritis in three commercial broiler breeds. Res. Vet. Sci. 2015, 102, 150-158. [CrossRef] [PubMed]

216. Shimouchi, A.; Nose, K.; Takaoka, M.; Hayashi, H.; Kondo, T. Effect of dietary turmeric on breath hydrogen. Dig. Dis. Sci. 2009, 54, 1725-1729. [CrossRef] [PubMed]

217. Feng, W.; Wang, H.; Zhang, P.; Gao, C.; Tao, J.; Ge, Z.; Zhu, D.; Bi, Y. Modulation of gut microbiota contributes to curcumin-mediated attenuation of hepatic steatosis in rats. Biochim. Biophys. Acta 2017, 1861, 1801-1812. [CrossRef] [PubMed]

218. Teixeira, T.F.; Collado, M.C.; Ferreira, C.L.; Bressan, J.; Peluzio Mdo, C. Potential mechanisms for the emerging link between obesity and increased intestinal permeability. Nutr. Res. 2012, 32, 637-647. [CrossRef] [PubMed]

219. Moreira, A.P.; Texeira, T.F;; Ferreira, A.B.; Peluzio Mdo, C.; Alfenas Rde, C. Influence of a high-fat diet on gut microbiota, intestinal permeability and metabolic endotoxaemia. Br. J. Nutr. 2012, 108, 801-809. [CrossRef] [PubMed]

220. Cani, P.D.; Bibiloni, R.; Knauf, C.; Waget, A.; Neyrinck, A.M.; Delzenne, N.M.; Burcelin, R. Changes in gut microbiota control metabolic endotoxemia-induced inflammation in high-fat diet-induced obesity and diabetes in mice. Diabetes 2008, 57, 1470-1481. [CrossRef] [PubMed]

221. Wang, J.; Ghosh, S.S.; Ghosh, S. Curcumin improves intestinal barrier function: Modulation of intracellular signaling, and organization of tight junctions. Am. J. Physiol. Cell Physiol. 2017, 312, C438-C445. [CrossRef] [PubMed] 
222. Song, W.B.; Wang, Y.Y.; Meng, F.S.; Zhang, Q.H.; Zeng, J.Y.; Xiao, L.P.; Yu, X.P.; Peng, D.D.; Su, L.; Xiao, B.; et al. Curcumin protects intestinal mucosal barrier function of rat enteritis via activation of MKP-1 and attenuation of p38 and NF-KB activation. PLoS ONE 2010, 5, e12969. [CrossRef] [PubMed]

223. Tian, S.; Guo, R.; Wei, S.; Kong, Y.; Wei, X.; Wang, W.; Shi, X.; Jiang, H. Curcumin protects against the intestinal ischemia-reperfusion injury: Involvement of the tight junction protein ZO-1 and TNF-alpha related mechanism. Korean J. Physiol. Pharmacol. 2016, 20, 147-152. [CrossRef] [PubMed]

224. Ghosh, S.S.; Bie, J.; Wang, J.; Ghosh, S. Oral supplementation with non-absorbable antibiotics or curcumin attenuates western diet-induced atherosclerosis and glucose intolerance in $1 \mathrm{dlr}^{-/}$mice-Role of intestinal permeability and macrophage activation. PLOS ONE 2014, 9, e108577. [CrossRef] [PubMed]

225. Hou, H.T.; Qiu, Y.M.; Zhao, H.W.; Li, D.H.; Liu, Y.T.; Wang, Y.Z.; Su, S.H. Effect of curcumin on intestinal mucosal mechanical barrier in rats with non-alcoholic fatty liver disease. Chin. J. Hepatol. 2017, 25, 134-138.

226. Wu, J.J.; Bennett, A.M. Essential role for mitogen-activated protein (map) kinase phosphatase-1 in stress-responsive map kinase and cell survival signaling. J. Biol. Chem. 2005, 280, 16461-16466. [CrossRef] [PubMed]

227. Ye, J.; Ding, M.; Zhang, X.; Rojanasakul, Y.; Shi, X. On the role of hydroxyl radical and the effect of tetrandrine on nuclear factor- KB activation by phorbol 12-myristate 13-acetate. Ann. Clin. Lab. Sci. 2000, 30, 65-71. [PubMed]

228. Ghosh, S.S.; He, H.; Wang, J.; Gehr, T.W.; Ghosh, S. Curcumin-mediated regulation of intestinal barrier function: The mechanism underlying its beneficial effects. Tissue Barriers 2018, 6, e1425085. [CrossRef] [PubMed]

229. Patumraj, S.; Wongeakin, N.; Sridulyakul, P.; Jariyapongskul, A.; Futrakul, N.; Bunnag, S. Combined effects of curcumin and vitamin $\mathrm{C}$ to protect endothelial dysfunction in the iris tissue of STZ-induced diabetic rats. Clin. Hemorheol. Microcirc. 2006, 35, 481-489. [PubMed]

230. Han, J.; Pan, X.Y.; Xu, Y.; Xiao, Y.; An, Y.; Tie, L.; Pan, Y.; Li, X.J. Curcumin induces autophagy to protect vascular endothelial cell survival from oxidative stress damage. Autophagy 2012, 8, 812-825. [CrossRef] [PubMed]

231. Hu, T.Y.; Liu, C.L.; Chyau, C.C.; Hu, M.L. Trapping of methylglyoxal by curcumin in cell-free systems and in human umbilical vein endothelial cells. J. Agric. Food Chem. 2012, 60, 8190-8196. [CrossRef] [PubMed]

232. Rungseesantivanon, S.; Thenchaisri, N.; Ruangvejvorachai, P.; Patumraj, S. Curcumin supplementation could improve diabetes-induced endothelial dysfunction associated with decreased vascular superoxide production and pkc inhibition. BMC Complement. Altern. Med. 2010, 10, 57. [CrossRef] [PubMed]

233. Motterlini, R.; Foresti, R.; Bassi, R.; Green, C.J. Curcumin, an antioxidant and anti-inflammatory agent, induces heme oxygenase- 1 and protects endothelial cells against oxidative stress. Free Radic. Biol. Med. 2000, 28, 1303-1312. [CrossRef]

234. Kim, Y.S.; Ahn, Y.; Hong, M.H.; Joo, S.Y.; Kim, K.H.; Sohn, I.S.; Park, H.W.; Hong, Y.J.; Kim, J.H.; Kim, W.; et al. Curcumin attenuates inflammatory responses of TNF-alpha-stimulated human endothelial cells. J. Cardiovasc. Pharmacol. 2007, 50, 41-49. [CrossRef] [PubMed]

235. Pendurthi, U.R.; Rao, L.V. Suppression of transcription factor Egr-1 by curcumin. Thromb. Res. 2000, 97, 179-189. [CrossRef]

236. Li, L.; Sawamura, T.; Renier, G. Glucose enhances human macrophage LOX-1 expression: Role for LOX-1 in glucose-induced macrophage foam cell formation. Circ. Res. 2004, 94, 892-901. [CrossRef] [PubMed]

237. Oliver, J.M.; Stoner, L.; Rowlands, D.S.; Caldwell, A.R.; Sanders, E.; Kreutzer, A.; Mitchell, J.B.; Purpura, M.; Jager, R. Novel form of curcumin improves endothelial function in young, healthy individuals: A double-blind placebo controlled study. J. Nutr. Metab. 2016, 2016, 1089653. [CrossRef] [PubMed]

238. Margina, D.; Gradinaru, D.; Manda, G.; Neagoe, I.; Ilie, M. Membranar effects exerted in vitro by polyphenols-Quercetin, epigallocatechin gallate and curcumin-On huvec and jurkat cells, relevant for diabetes mellitus. Food Chem. Toxicol. 2013, 61, 86-93. [CrossRef] [PubMed]

239. Chen, M.; Masaki, T.; Sawamura, T. LOX-1, the receptor for oxidized low-density lipoprotein identified from endothelial cells: Implications in endothelial dysfunction and atherosclerosis. Pharmacol. Ther. 2002, 95, 89-100. [CrossRef]

240. Naito, T.; Oikawa, S.; Kotake, H.; Hayasaka, K.; Toyota, T. Effect of glucose concentration on foam cell formation in THP-1 cells. J. Atheroscler. Thromb. 2001, 8, 55-62. [CrossRef] [PubMed]

241. Karin, M.; Liu, Z.; Zandi, E. AP-1 function and regulation. Curr. Opin. Cell Biol. 1997, 9, 240-246. [CrossRef] 
242. Laight, D.; Carrier, M.; Anggard, E. Antioxidants, diabetes and endothelial dysfunction. Cardiovasc. Res. 2000, 47, 457-464. [CrossRef]

243. Boonla, O.; Kukongviriyapan, U.; Pakdeechote, P.; Kukongviriyapan, V.; Pannangpetch, P.; Prachaney, P.; Greenwald, S.E. Curcumin improves endothelial dysfunction and vascular remodeling in $2 \mathrm{~K}-1 \mathrm{C}$ hypertensive rats by raising nitric oxide availability and reducing oxidative stress. Nitric Oxide 2014, 42, 44-53. [CrossRef] [PubMed]

244. Sun, Y.; Hu, X.; Hu, G.; Xu, C.; Jiang, H. Curcumin attenuates hydrogen peroxide-induced premature senescence via the activation of Sirt1 in human umbilical vein endothelial cells. Biol. Pharm. Bull. 2015, 38, 1134-1141. [CrossRef] [PubMed]

245. Yao, Y.; Wang, W.; Li, M.; Ren, H.; Chen, C.; Wang, J.; Wang, W.E.; Yang, J.; Zeng, C. Curcumin exerts its anti-hypertensive effect by down-regulating the $\mathrm{AT}_{1}$ receptor in vascular smooth muscle cells. Sci. Rep. 2016, 6, 25579. [CrossRef] [PubMed]

246. Farhangkhoee, H.; Khan, Z.A.; Chen, S.; Chakrabarti, S. Differential effects of curcumin on vasoactive factors in the diabetic rat heart. Nutr. Metab. 2006, 3, 27. [CrossRef] [PubMed]

247. Srivastava, G.; Mehta, J.L. Currying the heart: Curcumin and cardioprotection. J. Cardiovasc. Pharmacol. Ther. 2009, 14, 22-27. [CrossRef] [PubMed]

248. Meng, Z.; Yan, C.; Deng, Q.; Gao, D.F.; Niu, X.L. Curcumin inhibits lps-induced inflammation in rat vascular smooth muscle cells in vitro via ROS-relative TLR4-MAPK/NF-kB pathways. Acta Pharmacol. Sin. 2013, 34, 901-911. [CrossRef] [PubMed]

249. Pardeshi, R.; Bolshette, N.; Gadhave, K.; Ahire, A.; Ahmed, S.; Cassano, T.; Gupta, V.B.; Lahkar, M. Insulin signaling: An opportunistic target to minify the risk of Alzheimer's disease. Psychoneuroendocrinology 2017, 83, 159-171. [CrossRef] [PubMed]

250. Chen, Y.; Deng, Y.; Zhang, B.; Gong, C.X. Deregulation of brain insulin signaling in Alzheimer's disease. Neurosci. Bull. 2014, 30, 282-294. [CrossRef] [PubMed]

251. De la Monte, S.M. Brain insulin resistance and deficiency as therapeutic targets in Alzheimer's disease. Curr. Alzheimer Res. 2012, 9, 35-66. [CrossRef] [PubMed]

252. Huang, Y.; Mucke, L. Alzheimer mechanisms and therapeutic strategies. Cell 2012, 148, 1204-1222. [CrossRef] [PubMed]

253. Price, J.L.; Ko, A.I.; Wade, M.J.; Tsou, S.K.; McKeel, D.W.; Morris, J.C. Neuron number in the entorhinal cortex and CA1 in preclinical Alzheimer disease. Arch. Neurol. 2001, 58, 1395-1402. [CrossRef] [PubMed]

254. Gomez-Isla, T.; Price, J.L.; McKeel, D.W., Jr.; Morris, J.C.; Growdon, J.H.; Hyman, B.T. Profound loss of layer II entorhinal cortex neurons occurs in very mild Alzheimer's disease. J. Neurosci. 1996, 16, 4491-4500. [CrossRef] [PubMed]

255. Prasad, K.; Tiwari, S. Therapeutic interventions for advanced glycation-end products and its receptormediated cardiovascular disease. Curr. Pharm. Des. 2017, 23, 937-943. [CrossRef] [PubMed]

256. Luevano-Contreras, C.; Gomez-Ojeda, A.; Macias-Cervantes, M.H.; Garay-Sevilla, M.E. Dietary advanced glycation end products and cardiometabolic risk. Curr. Diabetes Rep. 2017, 17, 63. [CrossRef] [PubMed]

257. Clifton, P.; Keogh, J. Role of dietary advanced glycation end products. Curr. Opin. Lipidol. 2017, $28,514-515$. [CrossRef] [PubMed]

258. Yamagishi, S.; Matsui, T. Pathologic role of dietary advanced glycation end products in cardiometabolic disorders, and therapeutic intervention. Nutrition 2016, 32, 157-165. [CrossRef] [PubMed]

259. Yan, S.D.; Chen, X.; Fu, J.; Chen, M.; Zhu, H.; Roher, A.; Slattery, T.; Zhao, L.; Nagashima, M.; Morser, J.; et al. Rage and amyloid-beta peptide neurotoxicity in Alzheimer's disease. Nature 1996, 382, 685-691. [CrossRef] [PubMed]

260. Donahue, J.E.; Flaherty, S.L.; Johanson, C.E.; Duncan, J.A., III; Silverberg, G.D.; Miller, M.C.; Tavares, R.; Yang, W.; Wu, Q.; Sabo, E.; et al. RAGE, LRP-1, and amyloid-beta protein in Alzheimer's disease. Acta Neuropathol. 2006, 112, 405-415. [CrossRef] [PubMed]

261. Ma, Q.L.; Yang, F.; Rosario, E.R.; Ubeda, O.J.; Beech, W.; Gant, D.J.; Chen, P.P.; Hudspeth, B.; Chen, C.; Zhao, Y.; et al. Beta-amyloid oligomers induce phosphorylation of tau and inactivation of insulin receptor substrate via c-jun N-terminal kinase signaling: Suppression by omega-3 fatty acids and curcumin. J. Neurosci. 2009, 29, 9078-9089. [CrossRef] [PubMed]

262. Zraika, S.; Hull, R.L.; Verchere, C.B.; Clark, A.; Potter, K.J.; Fraser, P.E.; Raleigh, D.P.; Kahn, S.E. Toxic oligomers and islet beta cell death: Guilty by association or convicted by circumstantial evidence? Diabetologia 2010, 53, 1046-1056. [CrossRef] [PubMed] 
263. Mukherjee, A.; Morales-Scheihing, D.; Butler, P.C.; Soto, C. Type 2 diabetes as a protein misfolding disease. Trends Mol. Med. 2015, 21, 439-449. [CrossRef] [PubMed]

264. Hartl, F.U. Protein misfolding diseases. Annu. Rev. Biochem. 2017, 86, 21-26. [CrossRef] [PubMed]

265. Sparks, S.; Liu, G.; Robbins, K.J.; Lazo, N.D. Curcumin modulates the self-assembly of the islet amyloid polypeptide by disassembling alpha-helix. Biochem. Biophys. Res. Commun. 2012, 422, 551-555. [CrossRef] [PubMed]

266. Daval, M.; Bedrood, S.; Gurlo, T.; Huang, C.J.; Costes, S.; Butler, P.C.; Langen, R. The effect of curcumin on human islet amyloid polypeptide misfolding and toxicity. Amyloid 2010, 17, 118-128. [CrossRef] [PubMed]

267. Wang, P.; Su, C.; Feng, H.; Chen, X.; Dong, Y.; Rao, Y.; Ren, Y.; Yang, J.; Shi, J.; Tian, J.; et al. Curcumin regulates insulin pathways and glucose metabolism in the brains of APPswe/PS1dE9 mice. Int. J. Immunopathol. Pharmacol. 2017, 30, 25-43. [CrossRef] [PubMed]

268. Wang, P.; Su, C.; Li, R.; Wang, H.; Ren, Y.; Sun, H.; Yang, J.; Sun, J.; Shi, J.; Tian, J.; et al. Mechanisms and effects of curcumin on spatial learning and memory improvement in APPswe/PS1dE9 mice. J. Neurosci. Res. 2014, 92, 218-231. [CrossRef] [PubMed]

269. Gong, Y.; Chang, L.; Viola, K.L.; Lacor, P.N.; Lambert, M.P.; Finch, C.E.; Krafft, G.A.; Klein, W.L. Alzheimer's disease-affected brain: Presence of oligomeric a beta ligands (addls) suggests a molecular basis for reversible memory loss. Proc. Natl. Acad. Sci. USA 2003, 100, 10417-10422. [CrossRef] [PubMed]

270. Taniguchi, C.M.; Emanuelli, B.; Kahn, C.R. Critical nodes in signalling pathways: Insights into insulin action. Nat. Rev. Mol. Cell Biol. 2006, 7, 85-96. [CrossRef] [PubMed]

271. Zhao, W.Q.; de Felice, F.G.; Fernandez, S.; Chen, H.; Lambert, M.P.; Quon, M.J.; Krafft, G.A.; Klein, W.L. Amyloid beta oligomers induce impairment of neuronal insulin receptors. FASEB J. 2008, 22, 246-260. [CrossRef] [PubMed]

272. Lublin, A.L.; Gandy, S. Amyloid-beta oligomers: Possible roles as key neurotoxins in alzheimer's disease. Mt. Sinai J. Med. 2010, 77, 43-49. [CrossRef] [PubMed]

273. O'Neill, C. PI3-kinase/Akt/mTOR signaling: Impaired on/off switches in aging, cognitive decline and alzheimer's disease. Exp. Gerontol. 2013, 48, 647-653. [CrossRef] [PubMed]

274. O'Neill, C.; Kiely, A.P.; Coakley, M.F.; Manning, S.; Long-Smith, C.M. Insulin and IGF-1 signalling: Longevity, protein homoeostasis and alzheimer's disease. Biochem. Soc. Trans. 2012, 40, 721-727. [CrossRef] [PubMed]

275. Wullschleger, S.; Loewith, R.; Hall, M.N. Tor signaling in growth and metabolism. Cell 2006, 124, 471-484. [CrossRef] [PubMed]

276. Wang, C.; Zhang, X.; Teng, Z.; Zhang, T.; Li, Y. Downregulation of PI3K/Akt/mTOR signaling pathway in curcumin-induced autophagy in APP/PS1 double transgenic mice. Eur. J. Pharmacol. 2014, 740, 312-320. [CrossRef] [PubMed]

277. He, Y.; Wang, P.; Wei, P.; Feng, H.; Ren, Y.; Yang, J.; Rao, Y.; Shi, J.; Tian, J. Effects of curcumin on synapses in APPswe/PS1dE9 mice. Int. J. Immunopathol. Pharmacol. 2016, 29, 217-225. [CrossRef] [PubMed]

278. Kim, S.J.; Son, T.G.; Park, H.R.; Park, M.; Kim, M.S.; Kim, H.S.; Chung, H.Y.; Mattson, M.P.; Lee, J. Curcumin stimulates proliferation of embryonic neural progenitor cells and neurogenesis in the adult hippocampus. J. Biol. Chem. 2008, 283, 14497-14505. [CrossRef] [PubMed]

279. Dong, S.; Zeng, Q.; Mitchell, E.S.; Xiu, J.; Duan, Y.; Li, C.; Tiwari, J.K.; Hu, Y.; Cao, X.; Zhao, Z. Curcumin enhances neurogenesis and cognition in aged rats: Implications for transcriptional interactions related to growth and synaptic plasticity. PLoS ONE 2012, 7, e31211. [CrossRef] [PubMed]

280. Belviranli, M.; Okudan, N.; Atalik, K.E.; Oz, M. Curcumin improves spatial memory and decreases oxidative damage in aged female rats. Biogerontology 2013, 14, 187-196. [CrossRef] [PubMed]

281. Bekinschtein, P.; Cammarota, M.; Katche, C.; Slipczuk, L.; Rossato, J.I.; Goldin, A.; Izquierdo, I.; Medina, J.H. BDNF is essential to promote persistence of long-term memory storage. Proc. Natl. Acad. Sci. USA 2008, 105, 2711-2716. [CrossRef] [PubMed]

282. Krabbe, K.S.; Nielsen, A.R.; Krogh-Madsen, R.; Plomgaard, P.; Rasmussen, P.; Erikstrup, C.; Fischer, C.P.; Lindegaard, B.; Petersen, A.M.; Taudorf, S.; et al. Brain-derived neurotrophic factor (BDNF) and type 2 diabetes. Diabetologia 2007, 50, 431-438. [CrossRef] [PubMed]

283. Navaratna, D.; Guo, S.Z.; Hayakawa, K.; Wang, X.; Gerhardinger, C.; Lo, E.H. Decreased cerebrovascular brain-derived neurotrophic factor-mediated neuroprotection in the diabetic brain. Diabetes 2011, 60, 1789-1796. [CrossRef] [PubMed] 
284. Andreassen, C.S.; Jakobsen, J.; Flyvbjerg, A.; Andersen, H. Expression of neurotrophic factors in diabetic muscle-Relation to neuropathy and muscle strength. Brain 2009, 132, 2724-2733. [CrossRef] [PubMed]

285. Karczewska-Kupczewska, M.; Kowalska, I.; Nikolajuk, A.; Adamska, A.; Zielinska, M.; Kaminska, N.; Otziomek, E.; Gorska, M.; Straczkowski, M. Circulating brain-derived neurotrophic factor concentration is downregulated by intralipid/heparin infusion or high-fat meal in young healthy male subjects. Diabetes Care 2012, 35, 358-362. [CrossRef] [PubMed]

286. Crawford, M.A.; Bazinet, R.P.; Sinclair, A.J. Fat intake and cns functioning: Ageing and disease. Ann. Nutr. Metab. 2009, 55, 202-228. [CrossRef] [PubMed]

287. Marszalek, J.R.; Lodish, H.F. Docosahexaenoic acid, fatty acid-interacting proteins, and neuronal function: Breastmilk and fish are good for you. Annu. Rev. Cell Dev. Biol. 2005, 21, 633-657. [CrossRef] [PubMed]

288. Wu, A.; Noble, E.E.; Tyagi, E.; Ying, Z.; Zhuang, Y.; Gomez-Pinilla, F. Curcumin boosts dha in the brain: Implications for the prevention of anxiety disorders. Biochim. Biophys. Acta 2015, 1852, 951-961. [CrossRef] [PubMed]

289. Pinkaew, D.; Changtam, C.; Tocharus, C.; Thummayot, S.; Suksamrarn, A.; Tocharus, J. Di-O-demethylcurcumin protects SK-N-SH cells against mitochondrial and endoplasmic reticulum-mediated apoptotic cell death induced by Abeta25-35. Neurochem. Int. 2015, 80, 110-119. [CrossRef] [PubMed]

290. Griffin, W. Inflammation and neurodegenerative diseases. Am. J. Clin. Nutr. 2006, 83, S470-S474. [CrossRef] [PubMed]

291. Li, Q.; Barres, B.A. Microglia and macrophages in brain homeostasis and disease. Nat. Rev. Immunol. 2018, 18, 225-242. [CrossRef] [PubMed]

292. Streit, W.J. Microglia as neuroprotective, immunocompetent cells of the cns. Glia 2002, 40, 133-139. [CrossRef] [PubMed]

293. Hanisch, U.K. Microglia as a source and target of cytokines. Glia 2002, 40, 140-155. [CrossRef] [PubMed]

294. Smith, W.L.; Garavito, R.M.; DeWitt, D.L. Prostaglandin endoperoxide H synthases (cyclooxygenases)-1 and -2. J. Biol. Chem. 1996, 271, 33157-33160. [CrossRef] [PubMed]

295. Bauer, M.K.; Lieb, K.; Schulze-Osthoff, K.; Berger, M.; Gebicke-Haerter, P.J.; Bauer, J.; Fiebich, B.L. Expression and regulation of cyclooxygenase-2 in rat microglia. Eur.J. Biochem. 1997, 243, 726-731. [CrossRef] [PubMed]

296. Kang, G.; Kong, P.J.; Yuh, Y.J.; Lim, S.Y.; Yim, S.V.; Chun, W.; Kim, S.S. Curcumin suppresses lipopolysaccharide-induced cyclooxygenase-2 expression by inhibiting activator protein 1 and nuclear factor kappab bindings in BV2 microglial cells. J. Pharmacol. Sci. 2004, 94, 325-328. [CrossRef] [PubMed]

297. Jin, C.Y.; Lee, J.D.; Park, C.; Choi, Y.H.; Kim, G.Y. Curcumin attenuates the release of pro-inflammatory cytokines in lipopolysaccharide-stimulated BV2 microglia. Acta Pharmacol. Sin. 2007, 28, 1645-1651. [CrossRef] [PubMed]

298. Karlstetter, M.; Lippe, E.; Walczak, Y.; Moehle, C.; Aslanidis, A.; Mirza, M.; Langmann, T. Curcumin is a potent modulator of microglial gene expression and migration. J. Neuroinflamm. 2011, 8, 125. [CrossRef] [PubMed]

299. Nair, A.B.; Jacob, S. A simple practice guide for dose conversion between animals and human. J. Basic Clin. Pharm. 2016, 7, 27-31. [CrossRef] [PubMed]

300. Jager, R.; Lowery, R.P.; Calvanese, A.V.; Joy, J.M.; Purpura, M.; Wilson, J.M. Comparative absorption of curcumin formulations. Nutr. J. 2014, 13, 11. [CrossRef] [PubMed]

301. Ghosh, S.; Bhattacharyya, S.; Rashid, K.; Sil, P.C. Curcumin protects rat liver from streptozotocin-induced diabetic pathophysiology by counteracting reactive oxygen species and inhibiting the activation of p53 and MAPKs mediated stress response pathways. Toxicol. Rep. 2015, 2, 365-376. [CrossRef] [PubMed]

302. Sandur, S.K.; Pandey, M.K.; Sung, B.; Ahn, K.S.; Murakami, A.; Sethi, G.; Limtrakul, P.; Badmaev, V.; Aggarwal, B.B. Curcumin, demethoxycurcumin, bisdemethoxycurcumin, tetrahydrocurcumin and turmerones differentially regulate anti-inflammatory and anti-proliferative responses through a ros-independent mechanism. Carcinogenesis 2007, 28, 1765-1773. [CrossRef] [PubMed]

(C) 2018 by the authors. Licensee MDPI, Basel, Switzerland. This article is an open access article distributed under the terms and conditions of the Creative Commons Attribution (CC BY) license (http:/ / creativecommons.org/licenses/by/4.0/). 